\title{
AVALIAÇÃO DA RESPOSTA TECIDUAL FRENTE A DIFERENTES MATERIAIS DE FIXAÇÃO EM ENXERTOS ÓSSEOS AUTÓGENOS. ANÁLISE MICROSCÓPICA MORFOLÓGICA
}

\section{MARIZA AKEMI MATSUMOTO}

Tese apresentada à Faculdade de Odontologia de Bauru da Universidade de São Paulo, como parte dos requisitos para obtenção do grau de Doutor em Odontologia, área de Patologia Bucal. Orientador: Prof. Dr. Luís Antônio de Assis Taveira

(Edição Revisada) 


\section{Mariza Akemi Matsumoto}

18 de fevereiro de 1969

Bauru - SP

Filiação

$1991-1995$

1996

1998

$1998-1999$

2000-2002

Associações
Nascimento

Kunio Matsumoto

Victória Oshiro Matsumoto

Curso de Graduação em Odontologia pela Universidade do Sagrado Coração de Bauru $-\mathrm{SP}$

Professora Auxiliar das Disciplinas de Cirurgia e Traumatologia Bucomaxilofacial do Curso de Odontologia da Universidade do Sagrado Coração de Bauru - SP

Professora Assistente da Disciplina de Histologia Bucal do Curso de Odontologia da Universidade do Sagrado Coração de Bauru - SP

Mestrado em Patologia Bucal pela Faculdade de Odontologia de Bauru USP

Doutorado em Patologia Bucal pela Faculdade de Odontologia de Bauru USP

Sociedade Brasileira de Ensino e Pesquisa Odontológica - SBPqO

Associação Paulista de Cirurgiões Dentistas - APCD/ Bauru 
O essencial é invisivel aos olhos.

(Saint-Exup鑽y) 


\section{A Deus,}

por ituminar e abençoar o meu caminho;

Aos mens pais e minha família,

pelo amor e dedicação desmedidos...

dedico este trabathor 


\section{Agradecimentos Especiais}

Ao Professor Doutor LUíS ANTÔNIO DE ASSIS TAVEIRA, pela atenção nunca negada, pelas constantes demonstrações de amizade e respeito, e, sobretudo, confiança na orientação deste trabalho;

Ao Professor Doutor HUGO NARY FILHO, pela companhia segura em mais uma etapa de minha trajetória profissional e pessoal, pelo carinho e incentivo, e pelo exemplo de amor à profissão e ao ensino;

Ao Professor Doutor ALBERTO CONSOLARO, por abrir as portas da Disciplina de Patologia do Departamento de Estomatologia, pela acolhida e confiança depositada;

Muitissimo obrigada!! 


\section{Agradeço...}

Aos Professores das Disciplinas de Cirurgia e Traumatologia Bucomaxilofacial da Universidade do Sagrado Coração de Bauru, Hugo Nary Filho, Aparício Fiúza de Carvalho Dekon, Roberto Yoshio Kawakami, Luís Eduardo Marques Padovan, Paulo Domingos Ribeiro Junior, Eduardo Sanches Gonçales e Ricardo Falcão Tuler, pela amizade e carinho, e pelo privilégio de têlos em minha companhia na vida profissional e pessoal;

À minha grande amiga Fernandinha, pela presença constante desde a fase pré-mestrado, pelo apoio e carinho, incentivo e auxílio profissional e pessoal;

Aos Professores da Disciplina de Patologia - Departamento de Estomatologia, da Faculdade de Odontologia de Bauru, Universidade de São Paulo, Dr. Alberto Consolaro, Dr. Luís Antônio de Assis Taveira e Dra. Vanessa Soares Lara, por me acolherem por todos estes anos, e participarem do meu crescimento profissional, e à Professora Doutora Denise Tostes de Oliveira, pelo incentivo e auxílio no desenvolvimento deste trabalho;

À Irmã Marizabel Leite, por possibilitar a concretização de minhas aspirações profissionais; 
Aos Professores Dr. Luís Casati Álvares, Dr. Carlos Eduardo Francischone e Dra. Cláudia de Almeida Prado Piccino Sgavioli, verdadeiros exemplos de dedicação ao ensino, pela confiança e pelas oportunidades de crescimento profissional;

Aos Funcionários da Disciplina de Patologia - Departamento de Estomatologia, da Faculdade de Odontologia de Bauru, Universidade de São Paulo, Fatiminha, Cristina e Bernadete, pela torcida, incentivo e amizade, e ao Sr. Valdir, pela correção do vernáculo;

À Maira, pela dedicação e paciência na confecção do material histológico;

Aos queridos amigos Regininha e Daniel, que apesar da distância física, estiveram sempre presentes em todos os momentos;

Ao Professor José Afonso Leirião, pelo auxílio nas horas difíceis;

Aos colegas do Curso de Pós-graduação, especialmente dos Cursos de Mestrado e Doutorado em Patologia;

Aos estagiários da Disciplina de Cirurgia e Traumatologia Bucomaxilofacial da Universidade do Sagrado Coração de Bauru, Marcelo, Eduardo, Tiago, Daniela, Carlinhos, Fabíola, Murilo, Michele e Verena, pelo trabalho dedicado na participação das fases cirúrgicas, e colaboração em todas as nossas atividades; 
Às Sras. Aparecida e Neusa, pela dedicação e empenho no agendamento dos pacientes;

A todos os pacientes que participaram deste trabalho, de forma despretensiosa e colaborativa, tornando possível o seu desenvolvimento;

Aos Funcionários do Setor de Odontologia da Universidade do Sagrado Coração de Bauru pelos serviços nunca negados;

Aos Funcionários da Biblioteca e do setor de pós-graduação da Faculdade de Odontologia de Bauru - USP, pela atenção e orientação dispensadas.

Meus sinceros agradecimentos!! 
Agradecimentos Institucionais

À Direção da Universidade do Sagrado Coração de Bauru, na pessoa da Magnífica Reitora Ir. JACINTA TUROLO GARCIA;

À Direção da Faculdade de Odontologia de Bauru, Universidade de São Paulo, na pessoa da Diretora Professora Doutora MARIA FIDELA DE LIMA NAVARRO;

À Comissão de Pós-Graduação da Faculdade de Odontologia de Bauru, na pessoa do Presidente Professor Doutor JOSÉ CARLOS PEREIRA. 


\section{SUMÁRIO}

LISTA DE FIGURAS

LISTA DE TABELAS.

RESUMO.

1 INTRODUÇÃO.

2 REVISÃO DE LITERATURA...................................................................

2.1 Reconstrução de rebordos atróficos com enxertos ósseos 5

Autógenos

2.2 Materiais de fixação interna em cirurgia bucomaxilofacial ................. 24

3 ProposiçÃo .................................................................................. 62

4 MATERIAL E MÉtOdOS ......................................................................

4.1 Seleção e preparo dos pacientes ................................................ 63

4.2 Procedimentos cirúrgicos e obtenção dos espécimes ..................... 65

4.3 Preparo dos espécimes ........................................................

4.4 Análise microscópica morfológica descritiva................................. 76

5 RESULTADOS ......................................................................................

5.1 Espécimes referentes aos enxertos ósseos fixados com parafusos de Titânio

5.2 Espécimes referentes aos enxertos ósseos fixados com parafusos de PLA/PGA

6 DiscUSSÃO............................................................................................

7 CONCLUSÕES .................................................................................... 106

ANEXOS .................................................................................................

REFERÊNCIAS BIBLIOGRÁFICAS ................................................................ 111

ABSTRACT........................................................................................... 


\section{LISTA DE FIGURAS}

Figura 1 - Representação esquemática das regiões poliméricas amorfas e cristalinas.

Figura 2- a) Aspecto clínico da região anterior de maxila a ser reconstruída; b) exposição da região receptora, exibindo o defeito ósseo; c) linha de incisão em mucosa labial.da área doadora.

Figura 3- a) Divulsão por planos e exposição da área doadora; b) ostectomia realizada com serra pneumática; c) bloco ósseo removido.

Figura 4 - Fixação dos blocos ósseos ao leito receptor com parafusos de fixação de titânio, em a) vista frontal e b) vista oclusal.

Figura 5 - Material de fixação LactoSorb. a) Chaves e brocas específicas para manipulação do material reabsorvível; b) chave para rosqueamento do parafuso reabsorvível; a linha pontilhada indica a região de fratura da extensão do parafuso.

Figura 6 - Material de fixação de titânio. a) Chave e brocas específicas 71 para inserção do material; b) parafuso de titânio do sistema 1.5..

Figura 7 - Inserção dos parafusos de teste no bloco ósseo: a) reabsorvível e b) de titânio.

Figura 8 - a) Preenchimento dos espaços entre os fragmentos com osso triturado; b) cobertura mucosa e sutura 
Figura 9- Aspecto macroscópico do espécime removido das regiões ocupadas pelos parafusos de teste com tecido ósseo adjacente para análise da interface.

Figura 10 - Espécime de grupo controle, evidenciando fragmento ósseo apresentando região central previamente ocupada pelo parafuso preenchida por hemácias $(*)$. (Coloração Tricrômico de Mallory; aumento original: $50 \mathrm{x}$ )

Figura 11 - Aspecto do tecido ósseo adjacente, do tipo cortical, constituído pelos canais de Havers (setas grandes). As lacunas ósseas apresentam-se preenchidas por osteócitos, caracterizando viabilidade morfológica do tecido (setas pequenas). (Coloração H.E.; aumento original: $\mathrm{a}=50 \mathrm{x} ; \mathrm{b}=$ 400x)

Figura 12 - Aspecto das superfícies ósseas, adjacentes à área ocupada pelo parafuso de titânio, mostrando ora ausência de células ou tecido conjuntivo (setas pequenas), ora células de revestimento (setas grandes). (Coloração H.E.; aumento original: $a=400 x$; coloração Tricrômico de Mallory; aumento original: $b=400 x) \ldots . .$.

Figura 13 - Espécime referente ao parafuso de PLA/PGA, exibindo fragmento ósseo apresentando região central preenchida por fragmentos irregulares birrefringentes referentes à permanência do material reabsorvível $(*)$. (Coloração Tricrômico de Mallory; aumento original: $\mathrm{a}=50 \mathrm{x}$

Figura 14 - Tecido conjuntivo fibroso interposto entre a região previamente ocupada pelo parafuso e o tecido ósseo adjacente, apresentando feixes de fibras colágenas organizados paralelamente entre si $(*)$. (Coloração H.E.; aumento original: a = 100x; coloração Tricrômico de Mallory; aumento original: $b=$ $100 x)$ 
Figura 15 - Fragmentos irregulares birrefringentes referentes à fragmentação do material reabsorvível (*). Eventuais leucócitos mononucleares foram visualizados no tecido conjuntivo fibroso (setas). (Coloração H.E.; aumento original: $\mathrm{a}=100 x$; coloração Tricrômico de Mallory; aumento original: $b=100 x$ )

Figura 16 - Aspecto microscópico evidenciando células gigantes multinucleadas tipo corpo estranho associadas à presença do material reabsorvível (setas). (Coloração Tricrômico de Mallory; aumento original: $a=100 x ; b=400 x$ )

Figura 17- Destaque das células gigantes multinucleadas tipo corpo estranho associadas aos fragmentos do parafuso reabsorvível (setas). (Coloração H.E.; aumento original: $a=400 x$; coloração Tricrômico de Mallory; aumento original: $b=400 x$ )

Figura 18 - Camada endosteal constituída por células de revestimento (setas pequenas). Presença de eventuais osteoclastos na superfície óssea (setas grandes). (Coloração Tricrômico de Mallory; aumento original: $a ; b=400 x$ ) 


\section{LISTA DE TABELAS}

Tabela 1 - Caracterização da amostra.......................................... 64 


\section{RESUMO}

Os enxertos ósseos autógenos têm sido largamente empregados para a reconstrução de rebordos atróficos. A fixação destes enxertos é fundamental no fenômeno de reparação óssea, propiciando a incorporação ao leito receptor e rápida revascularização. Placas e parafusos sintéticos reabsorvíveis têm sido desenvolvidos na tentativa de minimizar alguns pontos negativos dos materiais metálicos rotineiramente utilizados para esta finalidade. O presente estudo avaliou comparativamente as condições ósseas locais de enxertos ósseos autógenos oriundos da região mentoniana quando em contato com parafusos de ácido poliglicólico (PGA)/ácido poli (L-láctico) (PLA) e de titânio. Para esta avaliação, participaram sete pacientes apresentando atrofias maxilar e mandibular severas, impossibilitando a reabilitação com implantes osteointegráveis. Após quatro meses das cirurgias de enxerto, as áreas onde se localizavam os parafusos de teste foram biopsiadas com brocas trefinas, obtendo-se os espécimes a serem submetidos a procedimento histotécnico de rotina e corados em H.E. e Tricrômico de Mallory para avaliação morfológica em microscopia óptica de luz. A partir desta análise observouse, adjacente aos parafusos de titânio, tecido ósseo viável, com eventuais áreas recobertas por células de revestimento e ausência de reabsorção. Adjacente aos parafusos reabsorvíveis, o tecido ósseo também apresentou viabilidade morfológica, porém, com presença de extensa faixa de tecido conjuntivo fibroso interposto, e eventuais células gigantes. Estes resultados sugerem que ambos os métodos de fixação proporcionaram condição de reparo no local de enxertos, contudo, os 
parafusos reabsorvíveis induziram reação inflamatória mais extensa que os de titânio, caracterizada por reação tipo corpo estranho. 


\section{INTRODUÇÃO}

Os enxertos autógenos têm sido largamente empregados para a reconstrução

de rebordos atróficos a serem reabilitados com implantes osteointegáveis obtendose resultados satisfatórios ${ }^{52,83,91}$. Inúmeros estudos foram realizados a fim de se analisar o melhor tipo de área doadora, bem como a melhor abordagem cirúrgica, com a finalidade de se criar condições para que o processo de reparo do enxerto ósseo aconteça de maneira favorável e obtenha-se uma área que apresente quantidade e qualidade satisfatórias para a instalação dos implantes ${ }^{46,54,64,77,91}$.

Estudos comparando tipos de áreas doadoras considerando sua origem embriológica comprovam, atualmente, que este não seria o fator relevante para obter-se um tecido ósseo de melhor ou pior qualidade ${ }^{5,38,98}$. Considera-se, sim, a arquitetura original do tecido ósseo a ser transplantado prevendo-se o seu grau de reabsorção. A fixação do enxerto ósseo também desempenha papel fundamental para este fenômeno de reparação. Em estudos como os de PHILLIPS; RAHN ${ }^{73}$, 
1990, demonstraram melhor incorporação e mais rápida revascularização dos enxertos quando estes são fixados rigidamente ao leito receptor.

Os materiais mais largamente empregados para esta finalidade são os parafusos metálicos. Sua ampla utilização como método de fixação interna, especificamente em traumatologia, dentro da área de cirurgia bucomaxilofacial, oferecem subsídios para o entendimento de seu comportamento biológico e clínico. No entanto, algumas desvantagens na utilização de componentes metálicos são observadas, como fratura do material, sensibilidade térmica, interferência nas técnicas radiográficas, além da necessidade de remoção destes ao longo do tempo, principalmente pela incerteza da composição e qualidade do metal que está sendo implantado e seu real comportamento no organismo humano ${ }^{1,34,82,84}$. Inevitável é, ainda, a remoção deste material quando utilizado para imobilizar áreas de enxertia óssea onde se objetiva a instalação de implantes osteointegráveis.

A fim de se minimizar as desvantagens trazidas pela utilização de placas e parafusos metálicos, novos materiais estão sendo desenvolvidos e adaptados à 
rotina da ortopedia, bem como da cirurgia bucomaxilofacial. Dentre eles, destacamse os polímeros reabsorvíveis, compostos por macromoléculas de alto peso molecular, como o polidioxanone (PDO), poligluconato, ácido poliglicólico (PGA), ácido poli L-láctico (PLA) e os copolímeros PLA/PGA ${ }^{74}$.

Apesar do número significativo de publicações referentes às variadas aplicações dos materiais de fixação reabsorvíveis ${ }^{11,28,29,33}$, não se observam estudos utilizando-os em cirurgias de reconstruções de rebordos alveolares para a reabilitação com implantes osteointegráveis.

Esta situação permitiria a não remoção do material de fixação na ocasião da instalação dos implantes o que, conseqüentemente, levaria a um acesso mais conservador da região. Igualmente, evitaria uma segunda intervenção cirúrgica em regiões críticas de enxerto e possibilitaria, ainda, a fixação de blocos ósseos em várias camadas, quando um volume ósseo maior fosse necessário.

Apesar de sua inerente vantagem sobre as fixações metálicas, sua ação local não deveria interferir sobre a qualidade do enxerto e o processo de reparação. Para 
o melhor entendimento de sua aplicação clínica, idealizou-se este estudo, buscando avaliar o comportamento do material de fixação de PLA/PGA quando em contato com fragmentos ósseos destinados à reconstrução de rebordos alveolares. 


\section{REVISÃO DE LITERATURA}

\subsection{Reconstrução de rebordos atróficos com enxertos ósseos autógenos}

A reabilitação de pacientes desdentados com implantes osteointegráveis e a possibilidade de substituição das próteses totais ou parciais removíveis por próteses fixas, sem o envolvimento de outras estruturas dentárias, incentivaram o desenvolvimento de novos sistemas de fixação, novas técnicas cirúrgicas e protéticas (DEPORTER et al. ${ }^{24}, 2001$; NARY FILHO; FRANCISCHONE; SARTOR6 ${ }^{68}$, 2002). Apesar disto, deficiências ósseas importantes, principalmente na região anterior de maxila, ainda hoje representam uma limitação às reabilitações, requerendo a realização de procedimentos específicos que permitam sua recuperação (NARY FILHO; ILG ${ }^{69}$, 2001).

Sem dúvida alguma, os enxertos ósseos autógenos permanecem como a melhor alternativa quando se objetiva ganho ósseo em regiões que irão receber 
implantes osteointegráveis, por sua capacidade osteogênica, osteoindutora e osteocondutora, além da ausência de imunogenicidade (BECKER et al. ${ }^{7}, 1996$; CITARDI et al. ${ }^{21}, 1994 ;$ LEE $^{51}, 1997$; LEVIN et al. ${ }^{53}, 1995 ;$ MARX $^{58}, 1994 ;$ MISCH $^{62}$, 1993; RABIE; LIE KEN JIE ${ }^{79}$, 1996)

Muito já se discutiu sobre a escolha das áreas doadoras, inicialmente levando-se em conta sua origem embriológica, intramembranosa ou endocondral (ALBERIUS; DAHLIN; LINDE ${ }^{4}$, 1992; LA TRENTA et al. ${ }^{49}$, 1989; PINHOLT et al. ${ }^{77}$, 1994; ZINS; WHITAKER ${ }^{99}$, 1983), posteriormente considerando-se sua estrutura arquitetural, cortical ou trabecular (MARX $\left.{ }^{58}, 1994\right)$.

Trabalhos clássicos como os de KUSIAK; ZINS; WHITAKER ${ }^{48}, 1985$, e ZINS; WHITAKER ${ }^{99}, 1983$, consideravam a origem embriológica dos enxertos como fator responsável pelos padrões de revascularização e reabsorção que estes sofriam com o passar do tempo. Estudos clínicos e experimentais posteriores, comparando estes dois tipos de ossos, acabaram por revelar a influência preponderante da arquitetura óssea nos seus padrões de sobrevivência. 
Para que pudessem avaliar a influência da origem embriológica dos enxertos ósseos, sua morfologia, além do modo de utilização destes enxertos no seu comportamento, HARDESTY; MARSH ${ }^{38}$, em 1990, utilizaram 46 coelhos adultos Nova Zelândia, os quais receberam três blocos ósseos posicionados nos ossos nasais. Foram removidos dois fragmentos unicorticais da calvária e um fragmento bicortical da crista ilíaca, para serem posicionados de três maneiras diferentes: com a cortical voltada para o osso receptor, com a porção medular voltada para o osso receptor, e o fragmento bicortical, com as corticais em contato com osso e periósteo. Administraram-se marcadores ósseos a cada 2, 4, 8 e 10 semanas. Vinte e um coelhos foram sacrificados após um mês e meio, e o restante após três meses. Observou-se que nos dois períodos, houve diferença estatisticamente significante nos quesitos volume, área e peso entre os dois tipos de enxerto, com resultados mais satisfatórios alcançados pelos enxertos intramembranosos, independente da orientação dos fragmentos. Ausência de incorporação óssea foi observada em 15\% de todos os enxertos endocondrais contra $4 \%$ dos intramembranosos. Uma maior 
porcentagem de osso neoformado também foi encontrado nos enxertos intramembranosos.

Os padrões de incorporação de enxertos de crista ilíaca e de calota craniana no esqueleto facial foram comparados por ALONSO et al. ${ }^{5}$, em 1995, em coelhos Nova Zelândia de 8 a 12 meses de idade. Sessenta animais foram divididos em dois grupos: o Grupo C, os quais receberam enxerto de calvária, e o Grupo I, que receberam enxerto de ilíaco. Blocos com cerca de $13 \mathrm{~mm}$ x $10 \mathrm{~mm}$ foram removidos das duas áreas doadoras, e antes de serem utilizados, foram minuciosamente medidos com paquímetros, pesados e tiveram seus volumes calculados. Os fragmentos foram posicionados nos ossos nasais e fixados com parafusos de aço inoxidável. Os períodos de sacrifício foram 18, 30 e 60 dias, quando os enxertos foram removidos e submetidos à mesma avaliação pré-cirúrgica, e posteriormente, preparados para análises microscópica e histomorfométrica. O Grupo C apresentou um aumento de peso significativo nos períodos de 18 e 30 dias, mantendo-se estável após 60 dias. Já o Grupo I mostrou redução significativa em espessura e 
volume aos 30 dias e em todas as medidas após 60 dias. Comparativamente, confirmou-se superioridade dos enxertos de calvária, apresentando números maiores em todas as medidas realizadas após 30 e 60 dias. Da análise histomorfométrica, observou-se neoformação óssea aos 60 dias em ambos os grupos, sendo esta maior no Grupo C.

Insatisfeitos com os resultados de trabalhos que avaliam a manutenção de enxertos ósseos de diferentes áreas doadoras, os quais consideram apenas a manutenção de volume dos mesmos, SOLHEIM, et al. ${ }^{87}$, em 1995, investigaram a quantidade de osso neoformado em fragmentos ósseos da calvária, mandíbula, tíbia e ilíaco, inseridos em tecido muscular de ratos. Os enxertos ósseos foram obtidos de sete ratos Lewis e posicionados nos músculos costais de dez outros ratos da mesma espécie. Os animais receberam estrôncio 85 na forma de $\mathrm{SrCl}_{2}$ e foram sacrificados após três semanas. O maior índice de neoformação óssea foi observado nos enxertos de calvária e mandíbula, comparados com o de crista ilíaca. No entanto, 
não se observou diferença entre os enxertos de calvária, mandíbula e ilíaco, ou entre a tíbia e o ílio.

OZAKI; BUCHMAN ${ }^{71}$, em 1998, compararam o comportamento de enxertos ósseos onlay de origem intramembranosa e endocondral em coelhos Nova Zelândia. Vinte e cinco coelhos receberam três tipos de enxertos, da região lateral da mandíbula, cortical do ilíaco e medular do ilíaco, os quais foram posicionados na calvária dos animais. Após três, oito e 16 semanas, os animais foram sacrificados e as áreas enxertadas foram removidas para análise microscópica, tomográfica e histomorfométrica. Os resultados mostraram que o enxerto de osso medular sofreu uma maior reabsorção, estatisticamente significante em comparação com os enxertos corticais. No entanto, não se observou diferença estatística na manutenção do volume entre os enxertos corticais, da mandíbula e do ilíaco, o que levou os autores a concluírem que a microarquitetura do tecido ósseo utilizado prevalece sobre sua origem embriológica. 
Do ponto de vista de OZAKI et al. ${ }^{72}$, além dos resultados que se observa com o emprego de enxertos ósseos autógenos de diferentes origens, com relação à manutenção de volume, índice de reabsorção, entre outros, interessa também conhecer o processo de remodelação destes enxertos em nível microarquitetural na medida em que ocorre sua incorporação ao leito receptor. Com este objetivo, desenvolveram um estudo no ano de 1999, onde observaram as diferenças microarquiteturais da porção cortical de enxertos onlay da crista ilíaca e da região lateral da mandíbula, posicionados na calvária de coelhos Nova Zelândia. As análises dos enxertos foram realizadas por meio de imagens obtidas por tomografia microcomputadorizada e microscopia óptica de luz após os períodos de 3, 8 e 16 semanas. Os resultados mostraram não haver diferença entre os enxertos corticais intramembranosos ou endocondrais, no que dizia respeito ao volume de tecido ósseo mineralizado, volume de superfície óssea ou número de trabéculas. As diferenças estatísticas só foram observadas quando se comparavam os períodos, principalmente o primeiro e o último, mas não quando se comparava os tipos de 
ossos, contrariando, assim, a maioria dos estudos realizados até então, sobre o comportamento dos enxertos de origens diferentes.

Concomitantemente, os resultados dos estudos experimentais incentivaram a realização de procedimentos clínicos tendo em vista a utilização de implantes osteointegráveis nas regiões reconstruídas.

A freqüência com que as áreas a receberem implantes osteointegráveis necessitam de preparo prévio e o comportamento dos implantes em áreas reconstruídas e não reconstruídas, foram caracterizados por MERAW et al. ${ }^{60}$ no ano de 1999, em estudo retrospectivo de pacientes tratados durante período de cinco anos. Quinhentos e quarenta e dois pacientes foram atendidos entre janeiro de 1993 e dezembro de 1997, recebendo 1.313 implantes. Destes, 58 áreas foram enxertadas com osso autógeno de regiões locais (25\%), osso autógeno de regiões distantes (43\%) e material não autógeno (33\%). Na maioria das vezes, os enxertos autógenos foram utilizados para reconstrução da região anterior de maxila. As perdas de implantes ocorreram em $8 \%$ dos casos reconstruídos com enxertos 
autógenos de regiões distantes e em $5,5 \%$ dos casos reconstruídos com enxertos não autógenos.

BREINE; BRANEMARK ${ }^{16}$ foram os primeiros a avaliar o uso de enxertos ósseos e implantes para a reconstrução de maxilas atróficas, em procedimento simultâneo e tardio realizado em humanos, no ano de 1980. No procedimento simultâneo, os implantes eram instalados em combinação com enxerto de tíbia; no tardio, aguardava-se a osteointegração dos implantes na própria zona doadora para que, após três a seis meses o conjunto fosse transportado para a maxila. Na técnica imediata, apenas $25 \%$ dos implantes permaneceram osteointegrados; na técnica tardia, alcançou-se índice de sucesso de $60 \%$, porém, com perda de $50 \%$ do volume ósseo inicial.

Em 1992, ISAKSSON; ALBERIUS ${ }^{41}$, publicaram um estudo retrospectivo realizado durante período de dois anos e oito meses, da utilização de implantes osteointegráveis imediatos em enxertos corticomedulares de crista ilíaca em maxilas atróficas. Quarenta e seis implantes foram utilizados em oito pacientes. Seis a nove 
meses após a cirurgia, procedeu-se a instalação dos cicatrizadores para confecção das próteses fixas. A avaliação da integração dos implantes foi realizada por meio de exames clínicos e radiográficos, logo após a instalação dos cicatrizadores, e posteriormente, anualmente, por um período de 32 a 64 meses. Oitenta e três por cento dos implantes apresentaram boa integração, sendo que um deles foi perdido antes da instalação dos cicatrizadores. Dois pacientes perderam dois implantes cada um devido à fratura do enxerto por traumatismo, e outros quatro foram removidos por falta de integração. Apesar do período de proservação limitado, os autores recomendam tal procedimento para o restabelecimento de maxilas atróficas.

SCHLIEPHAKE; NEUKAM; WICHMANN ${ }^{83}$, em 1997, analisaram o índice de sobrevivência de implantes instalados em enxertos de crista ilíaca e de mento, para reabilitação maxilar e mandibular. Oitocentos e trinta e três implantes foram instalados em blocos monocorticais removidos da parte anterior medial ou posterior lateral da crista ilíaca e 38 foram posicionados em enxertos ósseos de sínfise mandibular após três a quatro meses da cirurgia de enxerto. Perderam-se 74 
implantes em 23 pacientes, devido à ausência de osteointegração no momento da conexão do intermediário ou a um afrouxamento assintomático nos primeiros meses pós-operatórios. O menor índice de sobrevivência de implantes foi associado aos enxertos onlay de crista ilíaca $(66,4 \%)$, seguido pelos enxertos sinusais de ilíaco (70,5\%), e sínfise mandibular tipo onlay (75\%) e inlay (100\%).

A influência dos enxertos ósseos onlay na estabilidade dos implantes osteointegrados foi estudada por RASMUSSON et al. ${ }^{81}$, em trabalho comparativo em coelhos Nova Zelândia realizado no ano de 1998. A área doadora foi a calvária, de onde os enxertos ósseos eram removidos com brocas trefinas, e posteriormente posicionados nas metáfises proximais de uma das tíbias dos animais e fixados com o próprio implante. O lado controle não recebeu o enxerto ósseo, apenas o implante cuja posição permitia a exposição de quatro a cinco roscas, correspondente à espessura dos enxertos do grupo controle. Imediatamente após a instalação dos implantes e 4, 8, 16 e 24 semanas após as cirurgias, a estabilidade dos mesmos era testada por meio de medida da freqüência de ressonância. No último período, 
realizou-se medida de torque para remoção dos implantes e posterior remoção dos espécimes para análise microscópica. A estabilidade maior foi encontrada nos implantes da área enxertada, bem como o maior torque para remoção. Microscopicamente, notou-se boa incorporação dos implantes em ambos os grupos. Tais resultados, juntamente com os cálculos de distribuição de forças indicaram que os enxertos ósseos utilizados nestas condições aumentaram o suporte biomecânico dos implantes.

As alterações de volume dos enxertos ósseos autógenos em bloco onlay e dos particulados utilizados no seio maxilar (inlay) foram analisadas por JOHANSSON et al. ${ }^{43}$, em 2001, durante um período de seis meses. Dez indivíduos com idades entre 49 e 71 anos apresentando maxilas edêntulas, receberam enxerto de crista ilíaca em bloco onlay na região anterior vestibular da maxila, e enxerto particulado inlay nos seios maxilares. Tomografias computadorizadas em cortes paralelos ao palato duro foram realizadas para avaliação do volume dos enxertos na segunda semana pós-operatória e também após seis ou sete meses, antes da 
instalação dos implantes. Da análise destas imagens, não se observou diferença estatisticamente significante entre os dois tipos de enxertos utilizados, sendo que a média da diminuição do volume dos enxertos onlay após seis meses foi de $49,5 \%$, e dos enxertos inlay de $47 \%$. Um total de 68 implantes foram instalados, tanto nas áreas enxertadas como nas não enxertadas, com um índice de sucesso de $97 \%$ após um ano.

Contribuindo para um melhor entendimento do comportamento dos implantes osteointegráveis quando instalados em áreas de enxertos ósseos autógenos, WIDMARK; CARLSSON; IVANOFF ${ }^{96}$, em 2001, apresentaram os resultados de tratamentos realizados com proservação de três a cinco anos. Os procedimentos visaram reabilitar maxilas severamente atróficas, utilizando três métodos, a seguir: um grupo foi tratado com enxertos ósseos autógenos de crista ilíaca e implantes osteointegrados; o segundo grupo recebeu apenas os implantes com modificações na técnica convencional; e o terceiro grupo foi reabilitado apenas com próteses totais otimizadas. Cento e um implantes foram utilizados no grupo dos enxertos ósseos, 
com perda de $25 \%$ destes durante o período de avaliação, e 120 implantes no grupo sem enxerto, com perda de $13 \%$ no mesmo período. Observou-se que todas as perdas de implantes ocorreram nos primeiros dois anos pós-operatórios, estabilizando-se até o período de cinco anos. Um importante fator considerado na perda dos implantes, principalmente no grupo dos enxertos ósseos, foi o tabagismo.

Apesar da vasta utilização e da quantidade óssea oferecida, a morbidade causada em áreas doadoras como a crista ilíaca $\left(\right.$ AZEVEDO $^{6}, 2000$; LAURIE et al. ${ }^{50}$, 1984) e a instabilidade no seu padrão de sobrevivência, causaram preocupação crescente nos tratamentos das reconstruções, fazendo com que novas regiões, como a mandíbula, fossem amplamente exploradas.

MISCH et al ${ }^{66}$ apresentaram, no ano de 1992, os resultados da utilização do mento como área doadora em onze pacientes com atrofia maxilar. As considerações clínicas foram realizadas após quatro meses, na reabertura para instalação dos implantes osteointegráveis. Observou-se completa incorporação dos enxertos no rebordo remanescente, com volume suficiente para receber os implantes. As 
complicações pós-operatórias foram consideradas mínimas e contornáveis com procedimentos conservadores. Nenhum caso resultou em parestesia da região mentoniana ou dos dentes relacionados.

Ainda buscando áreas doadoras que promovessem menor morbidade ao paciente, $\mathrm{MISCH}^{63}$, no ano de 1996, revisou a técnica para obtenção de enxerto ósseo do ramo mandibular, enfatizando os cuidados a serem tomados, principalmente com injúrias ao nervo alveolar inferior, bem como as características biológicas deste osso, bastante semelhantes às do mento. No ano seguinte, comparou as regiões de sínfise e ramo mandibular em 50 pacientes a serem reabilitados com implantes osteointegráveis. As avaliações clínicas foram realizadas após quatro a seis meses da enxertia óssea, no momento da instalação dos implantes, observando-se a morfologia e o tamanho do enxerto, os níveis de reabsorção e incorporação, e a qualidade óssea. Constatou-se um maior volume dos enxertos de sínfise que os de ramo $\left(1,74 \mathrm{~cm}^{3}\right.$ e $0,9 \mathrm{~cm}^{3}$, respectivamente). No entanto, notou-se ocorrência de deiscência de sutura em 10,7\% da região de mento, 
além de parestesia temporária do nervo mentoniano em 9,6\% dos pacientes. Todos os 50 enxertos incorporaram e não se observou diferença clínica de níveis de reabsorção entre os dois tipos de enxerto. A maioria dos enxertos de ramo foi classificada como osso tipo I e grande parte dos enxertos de mento como osso tipo II.

Neste mesmo ano, a utilização de implantes em regiões de maxila e mandíbula reconstruídas com ossos provenientes da crista ilíaca, mento e calvária, foi avaliada por TRIPLETT; SCHOW ${ }^{94}$. Trezentos e sessenta e quatro implantes foram instalados em rebordos reconstruídos de 99 pacientes, submetidos a procedimentos variados, incluindo enxertos onlay, veneer, em sela, inlay e levantamento de seio maxilar. A instalação dos implantes foi realizada de duas maneiras: simultaneamente à cirurgia de enxerto e após seis a nove meses. Obtevese um índice maior de sucesso dos implantes nas instalações posteriores, 90,4\% contra $83,6 \%$ dos imediatos. De um modo geral, alcançou-se índice de sucesso de 
$87,9 \%$ de todos os implantes colocados em áreas enxertadas. A região doadora não afetou significativamente os resultados obtidos.

RAGHOEBAR et al. ${ }^{80}$, ainda em 1996, utilizaram enxertos ósseos autógenos de regiões da maxila e mandíbula para reconstruir áreas de rebordo atróficas em região anterior de maxila, possibilitando futura reabilitação com implantes. Dois grupos foram analisados; o grupo A, composto por 23 indivíduos parcialmente desdentados, e o grupo B, com quatro pacientes apresentando dentes a serem extraídos. No grupo A, 12 pacientes receberam enxertos em bloco removidos do mento, sete da área retromolar e quatro da tuberosidade maxilar, que foram posicionados na porção vestibular do rebordo e fixados com placas e parafusos. No grupo B, os alvéolos vazios resultantes das extrações, foram preenchidos com osso medular do túber. Após um intervalo de três meses, os implantes foram instalados e após seis meses, os cicatrizadores. O período de proservação variou entre 24 a 68 meses, sem que nenhum dos implantes fosse perdido. 
A falta de estudos que apresentassem resultados em longo prazo da utilização de implantes osteointegráveis em enxertos ósseos autógenos fez com que LEKHOLM et al. ${ }^{52}$, em 1999, desenvolvessem um trabalho retrospectivo de três anos com a contribuição de 23 clínicas da Escandinávia. Cento e cinqüenta pacientes com idades entre 16 e 72 anos foram incluídos no estudo, sendo que 145 receberam enxertos ósseos na maxila e cinco na mandíbula. Destes, 102 foram removidos da crista ilíaca, e 48 de regiões intrabucais, utilizando-se cinco técnicas diferentes onlay total e parcial, inlay, onlaylinlay, e osteotomia Le Fort I. Em cento e vinte e cinco casos, a instalação dos implantes foi imediata; nos outros 25, em um segundo procedimento, totalizando 624 implantes. Outros 157 implantes foram instalados em regiões não enxertadas. Dos implantes instalados simultaneamente aos enxertos, $23 \%$ foi perdido, contra $10 \%$ daqueles instalados posteriormente. Maior também foi o índice dos implantes colocados em regiões não enxertadas, cuja perda foi de $11 \%$, contra os colocados em áreas enxertadas, correspondendo a $25 \%$. Não se pôde concluir critérios de sucesso e falha a partir deste estudo. 
Para corrigir defeitos horizontais de rebordos maxilares e mandibulares desdentados, BEDROSSIAN; TAWFILIS; ALIJANIAN ${ }^{8}$ utilizaram, no ano de 2000, enxertos provenientes do ramo e corpo mandibular em 63 pacientes. A possibilidade de se obter fragmentos ósseos monocorticais de 25 a 30mm de extensão do corpo mandibular, e de 10 a $20 \mathrm{~mm}$ do ramo encorajou os autores a utilizá-los neste tipo de reconstrução. Cento e oitenta e sete implantes osteointegráveis foram instalados nas áreas enxertadas após quatro meses, permanecendo por mais três na mandíbula, e seis meses na maxila até a colocação dos pilares de cicatrização. Os pacientes foram reabilitados com 34 próteses unitárias e 54 próteses parciais, e acompanhados por um período médio de 38 meses. A facilidade de remoção destes enxertos, a possibilidade de executá-la em ambiente ambulatorial e a baixa morbidade decorrente do procedimento são vantagens enfatizadas pelos autores, além das características biológicas favoráveis deste tipo de enxerto.

Em 2001, SETHI; KAUS ${ }^{85}$ apresentaram os resultados preliminares do comportamento clínico de implantes osteointegráveis instalados em regiões 
reconstruídas com enxertos ósseos provenientes da mandíbula. Sessenta pacientes apresentando rebordos maxilares e mandibulares deficientes compuseram a amostra. Os enxertos ósseos foram removidos das regiões de sínfise e ramo, dependendo da extensão do defeito, e utilizados em bloco. Após três a seis meses, os implantes foram instalados e seis meses depois, foram postos em função. Dos 118 implantes instalados, apenas dois foram perdidos por exposição e infecção. Os pacientes foram observados até 0 período de 77 meses, sem nenhuma perda adicional.

\section{2- Materiais de fixação interna em cirurgia bucomaxilofacial}

O sucesso da reparação óssea depende de uma variedade de fatores que incluem as condições técnicas cirúrgicas, a manipulação dos fragmentos ósseos, a interação entre as superfícies, além de cuidados específicos que devem ser mantidos durante a fase pós-operatória. Um outro fator de grande relevância e, quiçá, decisivo para a consolidação óssea é a capacidade de imobilização dos 
fragmentos. Para a compreensão deste item é fundamental um estudo retrospectivo da origem e desenvolvimento destes dispositivos.

$\mathrm{Na}$ história das fraturas faciais, desde os tempos remotos, a imobilização da área afetada era motivo de preocupação para os cirurgiões da época, inicialmente realizada por meio de bandagens, posteriormente, pela técnica de fixação intermaxilar com fios de linho e ouro, confecção de goteiras para manutenção da anatomia, até a utilização dos fios de aço para osteossíntese direta introduzida no século XIX (DINGMAN; NATVIG ${ }^{25}, 1983$ ). No início do século XX, algumas tentativas de utilização de placas e parafusos de aço inoxidável e vitálio no tratamento de fraturas mandibulares foram realizadas com pouco sucesso, pois a falta de maleabilidade destes materiais resultava em fraturas freqüentes (HESLOP et al. ${ }^{39}$, 1994). Ainda assim, vários trabalhos foram desenvolvidos, demonstrando o valor desta técnica. Foi no ano de 1978 que CHAMPY et al. ${ }^{20}$ estabeleceram as bases científicas para a aplicação da fixação interna rígida em cirurgia bucomaxilofacial por meio da utilização de miniplacas de aço inoxidável para o tratamento de fraturas 
mandibulares, modificando a técnica inicialmente proposta por MICHELET; DEYMES; DESSUS ${ }^{61}$ em 1973.

Nos enxertos ósseos autógenos, especificamente, uma interação enxerto/área receptora favorável, advém em grande parte também, da capacidade de imobilização dos fragmentos para que os eventos de reparação possam acontecer, resultando em neoformação óssea e consolidação do enxerto.

LA TRENTA et al. ${ }^{49}$, em 1989, compararam a qualidade dos enxertos ósseos onlay e inlay, quando imobilizados com materiais de fixação interna rígida e com fios metálicos em cães, os quais receberam blocos de enxertos ósseos autógenos oriundos do arco zigomático e da crista ilíaca em três localidades diferentes de cada lado da face: mandíbula e maxila, pela técnica onlay, e arco zigomático, pela técnica inlay. De um lado a fixação foi feita com fios metálicos, do outro lado, com parafusos. Os animais foram sacrificados após 16 semanas, para avaliação de volume e peso dos enxertos. Constatou-se que a fixação rígida dos blocos ósseos aumentou o volume enxerto/osso. Microscopicamente, observou-se nítida união óssea dos 
fragmentos fixados com parafusos, porém, com predominância de faixa de tecido conjuntivo fibroso nos enxertos fixados com fios metálicos.

No ano seguinte, PHILLIPS; RAHN ${ }^{73}$ investigaram a relação entre reabsorção e revascularização óssea e a fixação dos enxertos ósseos. Vinte carneiros adultos receberam enxertos do osso parietal e da costela em ambos os lados na borda anterior da mandíbula, sendo que em somente um lado os mesmos foram fixados com parafusos de titânio. Os animais foram divididos em dois grupos, sendo o primeiro sacrificado após duas semanas, e o segundo após 20 semanas. Nos dois períodos, notou-se discreto deslocamento dos blocos ósseos que não haviam sido fixados, bem como um maior espaçamento na região de interface enxerto/osso. Pela administração de marcadores ósseos durante o experimento, pôde-se verificar, após duas semanas, maior área de revascularização dos enxertos intermembranosos fixados do que os não fixados. No entanto, resultado oposto foi obtido com os enxertos endocondrais. Após 20 semanas, todos os enxertos apresentavam completa revascularização. Com relação ao índice de reabsorção 
óssea, de um modo geral, tanto os enxertos endocondrais como os intramembranosos apresentaram menor índice de reabsorção quando fixados.

Neste mesmo ano, LIN et al. ${ }^{56}$ avaliaram os efeitos da fixação interna em enxertos ósseos onlay em área de pouca mobilidade, os ossos nasais, comparada com área de muita mobilidade, o fêmur. Para este estudo, utilizaram 54 coelhos Nova Zelândia, os quais tiveram os enxertos removidos da crista ilíaca e da calvária, sendo divididos em dois grupos: os animais do Grupo 1 tiveram os enxertos posicionados nos osso nasais, e o Grupo 2, no fêmur. Em ambos os grupos, quatro blocos dos enxertos foram posicionados; um dos fragmentos de cada tipo de osso foi fixado com parafusos lag-screw, e os outros permaneceram sem fixação. Após 14 semanas, os enxertos fixados mantiveram $56 \%$ do seu volume original, contra $46 \%$ dos não fixados. Quando se compararam as áreas receptoras, os enxertos fixos do fêmur apresentaram índice de sobrevivência significativamente maior que os não fixados. No entanto, os enxertos posicionados nos ossos nasais, não mostraram diferença quanto à sua fixação. 
Tais estudos revelam a importância da fixação interna em benefício do fenômeno de reparação óssea, por meio da utilização de placas e parafusos que permitem uma completa imobilização dos fragmentos.

Apesar de bem estabelecida e consagrada a aplicação destes materiais, algumas desvantagens na utilização de componentes metálicos começaram a ser observadas, como fratura do material, sensibilidade térmica, interferência nas técnicas radiográficas, além da necessidade de remoção destes ao longo do tempo, principalmente pela incerteza da composição e qualidade do metal que está sendo implantado (BOS et al. ${ }^{11}$, 1988; EDWARDS; KIELY ${ }^{28}$, 1998; PIETRZAK; SARVER; VERSTYNEN ${ }^{74}$, 1996; PIETRZAK; SARVER; VERSTYNEN $\left.{ }^{75}, 1997\right)$.

Manifestação de hipersensibilidade aos materiais metálicos, embora infreqüentes, já foram relatados. TORGERSEN; GILHUUS-MOE; GJERDET ${ }^{92}$, em 1993, testaram a reação de hipersensibilidade de 15 pacientes ao níquel presente nos materiais de aço inoxidável, por meio de teste de transformação blástica de linfócitos. Estes pacientes apresentavam miniplacas de aço inoxidável utilizadas 
para imobilização de fraturas mandibulares, as quais haviam permanecido por um período que variou entre 6 a 58 semanas. Quatro pacientes apresentavam sintomatologia no momento da remoção dos materiais. Colheram-se amostras de sangue de todos os pacientes previamente às cirurgias para realização do teste de transformação linfocitária, a fim de se mensurar in vitro o potencial imunogênico ao níquel de cada indivíduo. O mesmo teste foi repetido na ocasião da remoção das placas. Os resultados mostraram um aumento significativo de transformação linfocitária como resposta a estimulação pelo níquel $(0,5 \mu \mathrm{g} \mathrm{Ni} / \mathrm{ml})$ após a remoção das fixações, instigando maiores discussões sobre a necessidade de remoção posterior destes materiais.

A possibilidade de contaminação e colonização das superfícies destes materiais também constitui fator de preocupação, podendo levar ao desenvolvimento de patologias infecciosas, como a osteomielite. DOBBINS; SELIGSON; RAFF ${ }^{26}$, no ano de 1988, realizaram análise microbiológica de 28 materiais de fixação ortopédicos removidos, sem sinais clínicos de reação tecidual. O período de 
permanência das fixações variou entre 2 a 51 meses. Amostras do tecido subjacente às fixações, e das superfícies das próprias fixações, foram colhidas com swabs no momento de sua remoção. Também, as placas e parafusos foram analisados separadamente. Das 28 fixações observadas, seis foram positivas para cocos grampositivos, e três para estafilococos. Vinte apresentaram uma variedade de bactérias, com prevalência (75\%) de estafilococos coagulase-negativos. Nenhum organismo anaeróbio foi isolado ou cresceu nas culturas por submersão das fixações. Sugeriuse a contaminação dos materiais de fixação via incisão durante a cirurgia inicial. Porém, a inativação destes microrganismos, observada pela ausência de sinais clínicos de infecção, não pôde ser esclarecida.

Os comportamentos clínico e biológico do titânio também foram investigados por ACERO et al. ${ }^{1}$, em 1999. Os autores avaliaram 37 miniplacas de titânio puro removidas de 23 pacientes após período de 4 a 160 semanas, os quais apresentavam complicações clínicas como exposição, dor ou inflamação. O grupo controle foi constituído por 22 mini-placas removidas após três meses, de pacientes 
que não apresentavam quaisquer sinais de complicação. Amostras dos tecidos adjacentes aos implantes também foram obtidas para análise microscópica. A partir da análise da microscopia eletrônica de varredura, constatou-se uma boa osteointegração dos materiais em $81,8 \%$ dos casos, compatível com as características macroscópicas. Confirmou-se um índice de contaminação de 100\% das placas expostas, contra $36 \%$ dos casos assintomáticos. Em $80 \%$ dos espécimes analisados por meio de microscopia óptica de luz, evidenciaram-se depósitos de material granular pigmentado nos tecidos moles adjacentes, que, associados aos defeitos encontrados na superfície das placas pela microscopia eletrônica, sugeriram aos autores um rápido processo de corrosão do titânio, sem que isto prejudicasse a consolidação óssea dos materiais.

Além disto, a deteç̧ão de produtos de corrosão dos materiais metálicos tanto local quanto sistemicamente, pôde ser comprovada em investigações utilizando metodologia similar, por meio de microscopia eletrônica de varredura, 
análise de raios-X de energia dispersiva e espectofotometria de absorção atômica, como demonstram os trabalhos a seguir.

As superfícies ósseas adjacentes aos materiais de fixação foram examinadas por SCHLIEPHAKE et al. ${ }^{84}$, em 1993, para detectar a contaminação dos espécimes pelo titânio. O conteúdo de titânio presente no fígado, rins e pulmões de seis cobaias Göttingen, os quais receberam dois parafusos cada, foi determinado utilizando-se espectroscopia de absorção atômica e comparado a um grupo controle. Os resultados mostraram que as partículas de titânio haviam sido liberadas mecanicamente e depositadas na superfície óssea durante a preparação do leito cirúrgico. Após cinco meses das cirurgias, não mais se observavam as partículas na superfície óssea próxima aos implantes. A determinação da concentração de titânio em órgãos internos mostrou que os pulmões continham a maior quantidade do metal, em comparação aos rins e fígado. Todos os valores foram significativamente diferentes que os do grupo controle. 
TORGERSEN et al. ${ }^{93}$, em 1995, avaliaram o tecido mole e ósseo adjacente às miniplacas e parafusos de aço inoxidável, utilizadas para tratamento de fraturas ósseas dos maxilares de doze pacientes. Três pacientes com placas de titânio também foram incluídos. As miniplacas e parafusos de aço inoxidável foram removidos após 15 a 47 semanas da implantação, e os de titânio após 39 a 41 semanas. Nenhuma alteração clínica foi observada no momento da remoção. Os tecidos moles adjacentes a ambos os materiais apresentaram fibrose com áreas de discreta inflamação crônica. Observou-se, ainda, tecido conjuntivo entre o osso e os parafusos dos dois materiais. Partículas de aço inoxidável e de titânio de 5-50um de diâmetro foram encontradas tanto nos tecidos moles quanto no tecido ósseo próximo aos materiais metálicos. A quantidade de impregnação pelos metais variou entre as secções e as partículas se apresentaram em menor número no osso que no tecido mole.

JORGENSON et al. ${ }^{45}$, em 1997, também avaliaram as condições teciduais adjacentes a materiais de fixação interna de titânio puro, a fim de estudar a liberação 
local de partículas deste material. Amostras dos tecidos moles foram obtidos de quatro pacientes pediátricos previamente submetidos a procedimentos cirúrgicos craniofaciais, após 21 a 29 meses. Não foram detectadas partículas de metal nos fragmentos analisados. Somente pela análise de absorção atômica detectou-se titânio em três dos quatro espécimes.

A fim de se minimizar as desvantagens trazidas pela utilização da fixação interna confeccionada com metais, novos materiais estão sendo desenvolvidos e adaptados à rotina da ortopedia, bem como da cirurgia bucomaxilofacial. Dentre eles, destacam-se os polímeros reabsorvíveis, inicialmente empregados como material de sutura, compostos por macromoléculas de alto peso molecular. $\mathrm{O}$ polidioxanone (PDO), poligluconato, ácido poliglicólico (PGA), ácido poli láctico (PLA) e os copolímeros de ácido poliglicólico e polilático (PGA-PLA) (PIETRZAK; SARVER; VERSTYNEN ${ }^{74}$, 1996) compõem a matéria prima da grande maioria destes materiais. Estes polímeros podem apresentar uma microestrutura amorfa, quando suas cadeias poliméricas encontram-se aleatoriamente dispostas, ou 
cristalina, quando as cadeias poliméricas apresentam-se ordenadas (Figura 1). Sua degradação se dá por hidrólise.

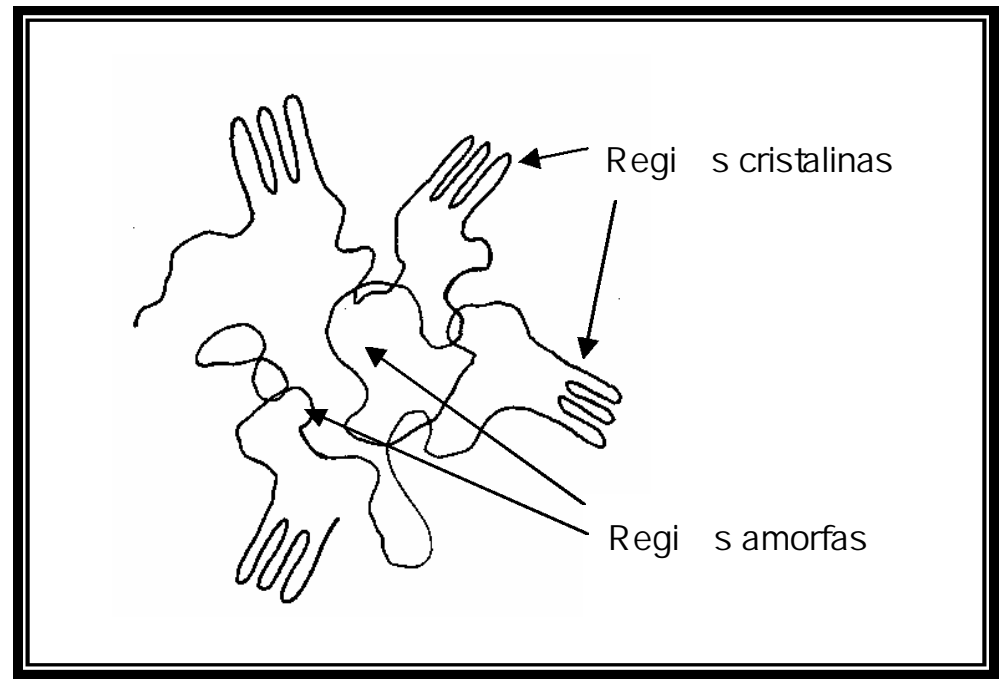

Figura 1 - Representação esquemática das regiões poliméricas amorfas e cristalinas

A partir de anos de estudo as pesquisas mostram que o PLA e o PGA são os polímeros mais adequados para a confecção de implantes reabsorvíveis. O homopolímero de PGA, embora altamente cristalino, é rapidamente reabsorvido pelo organismo, perdendo quase a totalidade de sua resistência em um mês e de sua 
massa entre 6 a 12 meses. Durante esta rápida reabsorção, grandes quantidades de monômero de PGA são liberadas, diminuindo o pH local. Dentre os materiais citados, apresenta a maior força de resistência.

A reabsorção do PLA é muito mais lenta, e pode levar vários anos, quando ela ocorre. Por ser um polímero semicristalino, suas áreas amorfas são mais rapidamente degradadas liberando partículas de cristais resistentes à degradação, passíveis de permanecerem por um tempo prolongado no local. Em sua forma pura, pode causar reação tipo corpo estranho.

Os materiais constituídos pelo copolímero PGA/PLA encontram um equilíbrio dos dois homopolímeros, onde se procura maximizar as características favoráveis de cada um, alcançando uma velocidade de reabsorção intermediária, lenta o bastante a fim de permitir a reparação do tecido ósseo, porém, rápida o suficiente para ser eliminada em cerca de um ano (MONTAG; MORALES; DAANE ${ }^{67}, 1997$; PIETRZAK; SARVER; VERSTYNEN ${ }^{75}$, 1997). Sua constituição física, química, mecânica, além 
das propriedades de degradação podem ser manipuladas alterando-se a proporção dos homopolímeros (LI' ${ }^{55}, 1999$; TEMENOFF; LU; MIKOS $\left.{ }^{89}, 2000\right)$.

Os trabalhos pioneiros da utilização destes polímeros como material de fixação pertencem à ortopedia, em suas diversas ramificações. Para que estes fossem aplicáveis, deveriam oferecer estabilidade funcional e boa biocompatibilidade até sua total degradação, o que levou à necessidade da combinação de alguns homopolímeros, somando-se as características inerentes a cada um deles, para que estes requisitos fossem alcançados.

CUTRIGHT et al. ${ }^{22}$, em 1974, testaram a utilização de materiais reabsorvíveis à base de PLA e PGA em diferentes proporções, a fim de encontrarem a composição que oferecesse a melhor fixação de fragmentos ósseos por quatro a dez semanas e que desaparecesse rapidamente após o reparo ósseo. Foram confeccionados cinco diferentes polímeros e copolímeros de PLA e PGA nas seguintes proporções: 100\% PLA, 75\% PLA e 25\% PGA, 50\% PLA e 50\% PGA, 25\% PLA e 75\% PGA, 100\% PGA. Realizou-se defeito ósseo na região de metáfise 
superior de cada fêmur de 275 ratas, utilizando-se uma broca esférica número seis, atingindo osso medular. Esferas destes materiais reabsorvíveis foram colocadas nos defeitos ósseos de cada perna dos animais. Os compostos de 100\% de PLA e PGA passaram por processo de resfriamento lento e rápido antes de serem implantados. A cada 20 dias cinco animais eram sacrificados, completando 220 dias. Os fêmures eram removidos, desmineralizados e corados com hematoxilina e eosina. Os espaços preenchidos ou previamente ocupados pelo material foram medidos em altura e largura. O processo de degradação do material seguiu sem reações inflamatórias. Observou-se que o primeiro material a sofrer degradação foi o composto por $25 \%$ de PLA e $75 \%$ PGA, seguido pelo 50\% PLA, 75\% PLA, 100\% PLA e por último o 100\% PGA. O resfriamento dos polímeros não alterou os índices de degradação. Notou-se que a substituição do material é feita por tecido conjuntivo fibroso e/ou tecido ósseo trabecular.

PIHLAJAMÄKI et al. ${ }^{76}$, em 1992, avaliaram a utilização de pinos de PLA para fixação de fraturas de pequenos fragmentos e osteotomias de mãos, pés, cotovelo e 
patela de 32 pacientes. Os implantes eram de 1,5 ou 2,0mm de diâmetro por 10 a $70 \mathrm{~mm}$ de comprimento. Dos pacientes operados, 27 foram proservados por um período mínimo de oito meses. Tomografias computadorizadas foram obtidas de três pacientes e em outros dois, foram realizadas biópsias das regiões do implante pela necessidade de nova intervenção aos 20 e 37 meses, devido à osteoartrite sintomática. Nenhum sinal de infecção ou inflamação foi observada nas regiões operadas. Os exames radiográficos não evidenciaram deslocamentos entre os fragmentos ósseos. Após 15 a 37 meses, as tomografias computadorizadas mostraram que os parafusos haviam desaparecido, porém, sem a formação de tecido ósseo nas lojas dos implantes. Microscopicamente, os espécimes removidos após 20 e 37 meses não mostraram células inflamatórias, assim como nenhum resquício de material polimérico. Os espaços anteriormente ocupados pelos pinos reabsorvíveis achavam-se preenchidos por tecido conjuntivo fibroso.

A fim de substituir os materiais convencionais utilizados em ortopedia, no intuito de se evitar principalmente as cirurgias para sua posterior remoção, 
YAMAMURO et al..$^{97}$, em 1994, apresentaram os resultados de sua avaliação clínica com a utilização de parafusos e pinos de PLA de força ultra-elevada, apresentando a maior força mecânica relatada até então. Cento e quarenta e três pacientes com idades entre 9 e 78 anos, foram operados e avaliados em um período de dois a seis anos. Todos os implantes de PLA foram instalados dentro ou próximos de articulações, em procedimentos que incluíram enxertos, fraturas, osteotomias e fixações temporárias. Classificaram-se as fixações como excelentes quando os ossos não apresentavam movimentação; boas, quando havia discreta movimentação; ruins, quando se necessitava de fixação externa e interna. Alcançaram-se $53,8 \%$ fixações consideradas excelentes, $44,1 \%$ boas e $2,1 \%$ ruins. Os achados radiográficos resultaram em $96,5 \%$ dos casos excelentes, $2,1 \%$ bons e $1,4 \%$ ruins. A união óssea não aconteceu em apenas um dos pacientes, submetido à cirurgia de enxerto em joelho. Verificaram-se $10 \%$ de perda de força inicial após oito semanas, $40 \%$ em 12 semanas e 100\% em 20 semanas. Diante dos resultados, os autores recomendaram a utilização deste material reforçado em praticamente todos 
os ossos do corpo, com exceção dos ossos longos, algumas fraturas de pélvis e tuberosidade tibial, onde os esforços e as forças requeridas são ainda maiores.

A partir da década de 70 , se inciaram os estudos da utilização deste tipo de material de fixação interna rígida em cirurgias craniomaxilofaciais cujas primeiras aplicações referiam-se ao tratamento das fraturas faciais, como o de GETTER et al. ${ }^{36}$, em 1972, os quais avaliaram a eficácia de placas e parafusos de PLA em fraturas mandibulares de cães, resultando em inúmeros estudos clínicos e experimentais para avaliação de sua aplicabilidade funcional e biológica.

BOS et al. ${ }^{11}$, em 1988, avaliaram a utilização de placas e parafusos de ácido PLA para fixação de fraturas de corpo mandibulares em cães. Seis animais participaram do estudo, cada um recebendo uma placa e quatro parafusos para a estabilização das fraturas criadas artificialmente em um dos lados da mandíbula. 0 lado oposto da mandíbula dos animais também recebeu o mesmo material, para futura comparação do índice de degradação das placas com e sem carga. A cada três semanas dois cães eram submetidos a exame das placas e parafusos de ambos 
os lados da mandíbula, sob anestesia geral, e também a avaliações radiográficas, completando nove semanas. Os materiais de fixação eram cuidadosamente removidos para posterior avaliação da força de tensão residual e determinação de seu peso molecular. A estabilidade das fraturas foi confirmada por meio de manipulação dos fragmentos. A avaliação clínica seguiu até 12 semanas após a primeira cirurgia. Não se observou alteração no processo de reparo ósseo ou reação inflamatória evidente causada pelo material utilizado. A remoção dos parafusos foi possível somente no período de três semanas; nos períodos subseqüentes, eles fraturavam na região entre a cabeça e a primeira rosca. As placas removidas das áreas de fratura apresentaram discreta diminuição na força de tensão, porém, não houve diferença com relação ao peso molecular.

O emprego dos materiais reabsorvíveis para fixação de fraturas ósseas em áreas de grande incidência de carga foi avaliado em animais por QUERESHY et al. ${ }^{78}$, no ano de 2000. Seis cães da raça Beagle foram submetidos a fraturas mandibulares iatrogênicas em região de ângulo com o uso de serra oscilatória. 
Quatro dos animais tiveram suas fraturas fixadas com placas e parafusos reabsorvíveis à base de PLA e PGA, na proporção de 82:18 do sistema LactoSorb (Walter Lorenz Surgical, Jacksonville, E.U.A.) . Os outros dois cães tiveram suas fraturas fixadas com material de titânio, servindo como grupo controle. Todos os animais foram radiografados previamente à cirurgia. Aos três e seis meses após a cirurgia, todos os animais eram radiografados e seus registros oclusais verificados. Apenas um animal foi sacrificado no período de três meses. Todos os outros foram sacrificados no período de seis meses. As mandíbulas foram removidas, desmineralizadas e preparadas para análise microscópica em coloração HE. Da análise clínica, nenhuma alteração local foi observada, com exceção de um animal do grupo controle que apresentou discreta deiscência de sutura. No sexto mês, já não era mais possível a visualização das linhas de fratura, radiograficamente. Microscopicamente, não se observou sinais de inflamação ou reação tipo corpo estranho aos materiais em ambos os grupos, com características normais de neoformação e remodelação óssea. 
$\mathrm{Na}$ área da pediatria, as fixações reabsorvíveis representam uma especial alternativa às fixações rígidas não reabsorvíveis pelas características inerentes à criança, de crescimento e desenvolvimento. Principalmente em cirurgias craniofaciais, as maiores preocupações do cirurgião quando da utilização de materiais de fixação metálicos são a restrição ao crescimento esquelético normal e a possibilidade de migração transcraniana destes materiais.

KUMAR et al. ${ }^{47}$, em 1997, relataram os resultados com o uso de fixação de PLA/PGA do sistema LactoSorb em 22 pacientes pediátricos submetidos a reconstruções craniofaciais variadas, cinco portadores de craniossinostose, uma excisão de dermóide nasal intracraniano, uma expansão orbital transcraniana para microftalmia, uma reconstrução de hemimandibulectomia devido a fibromatose juvenil, e uma Le Fort I para retrusão maxilar. Dentre os casos de traumatismo foram operados seis pacientes por fratura craniana, dois para craniotomia para drenagem de hematoma, e um submetido à cranioplastia com enxerto de costela para correção de defeito de calvária. Além disto, foram operadas mais quatro crianças, duas por 
fratura orbitária e duas por fraturas mandibulares. A idade dos pacientes variou entre 5 a 228 meses. As observações do controle pós-operatório correspondem a períodos de 2 a 16 semanas. Todos os pacientes apresentaram processo de reparo satisfatório sem sinais de infecção ou inflamação, com exceção de um paciente. As placas apresentaram fixação satisfatória.

Motivados pelos benefícios trazidos pelos materiais reabsorvíveis na pediatria, MONTAG; MORALES; DAANE ${ }^{67}$, neste mesmo ano, apresentaram os resultados clínicos de suas experiências com o uso deste mesmo tipo de material. Trinta e cinco crianças apresentando diversas alterações ósseas e duas fraturas de malar, foram tratadas com fixação à base de PLA/PGA, onde se utilizaram telas de $1,5 \mathrm{~mm}$ de espessura e cerca de 30 parafusos por cirurgia. Em nove dos pacientes utilizaram-se em conjunto, placas, parafusos e fios de aço, pela preocupação com a estabilidade do material. Os períodos de proservação foram de duas semanas, um, três e seis meses. Em cada visita o processo de reparo, contorno ósseo, estabilidade e a presença de placas visíveis foram verificados, com resultado 
negativo em todas as consultas. Em nove pacientes até os três primeiros meses, podia-se sentir a presença das placas à palpação. Pelos resultados obtidos neste estudo preliminar, os autores aprovaram a utilização deste tipo de material em cirurgias pediátricas, sem, no entanto, ressaltar a necessidade de acompanhamento por um período mais prolongado.

Casos de deformidades craniofaciais congênitas também já foram tratados empregando-se os materiais reabsorvíveis, como demonstraram GOLDSTEIN; QUERESHY; COHEN ${ }^{37}$, em 1997. Oito crianças, com idades entre seis meses e dez anos foram operadas, sendo sete casos de craniosinostose e um de encefalocele. Todas foram previamente submetidas a exame de tomografia computadorizada para confecção tridimensional da cabeça. Para as cirurgias, utilizou-se o sistema 1.5 da LactoSorb. Durante as visitas pós-cirúrgicas, não se observaram quadros de infecção, extrusão, exposição, eritema, instabilidade ou deslocamentos dos fragmentos ósseos. A maioria das placas era visível ou sentida à palpação, somente 
nos três primeiros meses. Os autores enfatizam que estes resultados foram obtidos em um período limitado de tempo, somente até seis meses.

Mais recentemente, a utilização deste tipo de material de fixação também foi adotada em cirurgias ortognáticas, onde a estabilidade óssea se faz de extrema relevância.

Com o objetivo de avaliar a eficácia de materiais de fixação de PLA/PGA do sistema LactoSorb, EDWARDS; KIELY ${ }^{28}$, no ano de 1998, avaliaram 29 pacientes, com idades entre 13 e 38 anos, os quais haviam sido submetidos a osteotomias Le Fort I; sendo 15 pacientes para avanço de maxila, cinco impacções e nove osteotomias segmentares. Independente da finalidade da osteotomia, a fixação foi feita de maneira similar: quatro placas $L$ e 16 parafusos 2,0 ou 2,5mm. Durante o período pós-operatório de acompanhamento, não se notou qualquer alteração local. Entre a primeira e a terceira semanas, alguns pacientes apresentaram discreta mobilidade da maxila à manipulação, estabilizando-se a partir da quarta semana. 
No ano de 2000, EDWARDS; KIELY; EPPLEY ${ }^{29}$ experimentaram a utilização de materiais de fixação reabsorvíveis em cirurgia de genioplastia. Vinte pacientes com idades entre 14 e 39 anos participaram do estudo, submetidos a cirurgias de avanço (média de 7,6mm), ajuste horizontal (média de 6,0 mm) e redução vertical (média de 7,0mm). As fixações foram realizadas com a utilização de placas e parafusos de PLA/PGA da LactoSorb. O acompanhamento pós-operatório variou entre um mês a dois anos. Durante este intervalo, não se observaram quadros de instabilidade nas fixações ou de reação inflamatória aos implantes. As baixas demandas biomecânicas da sínfise mandibular foram os maiores indicativos para a indicação destes materiais nestes tipos de osteotomias, segundo os autores.

Ampliando suas experiências com o uso de materiais reabsorvíveis em cirurgia ortognática, especialmente em osteotomias Le Fort I e sagitais de mandíbula, estes mesmos autores ${ }^{30}$, em 2001, comprovaram o uso destes em cirurgias bimaxilares. Vinte pacientes com idades entre 15 e 38 anos foram submetidos a osteotomias bimaxilares devido a deformidades faciais complexas. 
Para as osteotomias Le Fort I, utilizaram-se quatro placas $L$ de $20 \mathrm{~mm}$ e quatro parafusos de $2.0 \mathrm{~mm} \times 7 \mathrm{~mm}$ em cada placa. As osteotomias mandibulares foram estabilizadas tanto com placas lineares como com placas $L$ invertida e parafusos de $2.5 \mathrm{~mm} \times 15$ ou $17 \mathrm{~mm}$. As genioplastias foram fixadas com dois ou três parafusos de $2.5 \mathrm{~mm} \times 17 \mathrm{~mm}$. A média de avanço maxilar foi de $5,5 \mathrm{~mm}$ e mandibular de $5,0 \mathrm{~mm}$. Nenhum sinal de infecção, deiscência de sutura, instabilidade óssea ou má-oclusão foram verificados no período que sucedeu as cirurgias. Após duas a quatro semanas, sete pacientes apresentaram discreta mobilidade na maxila, que se estabilizaram após cinco a seis semanas. Radiograficamente constataram-se a consolidação óssea e a integridade dos seios maxilares. Os orifícios dos parafusos eram visualizados com dificuldade na maxila; porém, na mandíbula, ainda eram evidentes mesmo após um ano das cirurgias, nos 13 pacientes que completaram este período de avaliação. Todas as cirurgias alcançaram sucesso, sem necessidade de novas intervenções ou evidência de reações teciduais indesejáveis, comprovando a eficácia destes materiais neste tipo de intervenção. 
Trabalhos experimentais comparativos empregando material reabsorvível e de titânio também foram realizados na fixação de enxertos ósseos autógenos.

Em 1994, EPPLEY; SADOVE ${ }^{32}$ procederam a cirurgia para remoção de enxertos da região parietal da calvária, bilateralmente em coelhos Nova Zelândia de seis meses de idade. Os enxertos ósseos foram removidos, rotacionados em $180^{\circ} \mathrm{e}$ reposicionados novamente na própria área doadora. Para a fixação destes fragmentos, empregaram-se placas reabsorvíveis do sistema LactoSorb em um lado, e do outro, placas metálicas, fixadas por cinco parafusos cada uma. Os sacrifícios aconteceram após 2, 6, 9 e 12 meses para a remoção dos espécimes e posterior análise em microscopia óptica de luz. Os resultados mostraram que após dois meses não se verificaram traços de inflamação nos tecidos adjacentes ao material reabsorvível, incluindo a região de dura-máter e tecido encefálico. Macroscopicamente, não se observou alteração no tamanho das placas ou dos parafusos, também no mesmo período. Aos seis meses, muito pouco se visualizou do material, alcançando-se completo reparo ósseo. Não se evidenciaram sinais de 
inflamação no tecido conjuntivo circunjacente. A visualização do material não foi mais possível no período de nove meses; no entanto, ainda havia a persistência de uma fina faixa de tecido conjuntivo fibroso revestindo a calvária. Este mesmo quadro microscópico se repetiu aos 12 meses.

No intuito de verificar a estabilidade de enxertos ósseos onlay com o uso de material reabsorvível, THALLER et al. ${ }^{90}$, em 1996, o compararam com parafusos de titânio em estudo realizado com coelhos Nova Zelândia. Quarenta animais receberam enxertos autógenos do arco zigomático nos osso nasais, bilateralmente, fixados com parafusos de titânio de um lado, e do outro com parafusos de PGA. Após duas, quatro, seis, oito e dez semanas os animais foram sacrificados para remoção das áreas enxertadas a serem analisadas quanto ao volume e aspecto microscópico. Menor índice de reabsorção dos enxertos foi observado no grupo do material reabsorvível que os enxertos fixados com parafusos de titânio, observado principalmente após o período de seis semanas. Microscopicamente, notou-se formação de faixa de fibrose com eventual reação tipo corpo estranho adjacente aos 
parafusos de PGA, porém, com remodelação do tecido ósseo, quadro este evidente no último período do experimento. Já nos enxertos fixados com parafusos de titânio, uma camada de tecido conjuntivo fibroso denso foi observada circundando o enxerto.

Apesar dos inúmeros estudos já realizados sobre os diversos polímeros na área da ortopedia e cirurgia bucomaxilofacial, e comprovada sua eficiência funcional e biocompatibilidade clínica satisfatória, alguns autores relatam eventuais alterações teciduais importantes decorrentes, principalmente, do seu processo de degradação.

O desenvolvimento ocasional de fístulas assépticas, apresentando conteúdo rico em leucócitos mononucleares linfócitos em regiões associadas a material de fixação reabsorvível de PGA, levou SANTAVIRTA et al.$^{82}$, em 1990, a estudarem sua capacidade imunogênica. Linfócitos mononucleares de sangue periférico doado por cinco voluntários saudáveis foram cultivados em $0,2 \mathrm{ml}$ de $\triangle \mathrm{AFCS}-\mathrm{RPMI} 1640 \mathrm{com}$ 10mg de PGA. Fitoemaglutinina lectina, uma proteína derivada da tuberculina, foi utilizada como grupo controle positivo, e como controle negativo, um meio de cultura 
livre. A ativação linfocitária foi observada nos dias zero, um, três e cinco. O método do complexo avidina-biotina-peroxidase foi utilizado para se evidenciar a expressão do antígeno do locus II do MHC e do receptor de interleucina-2, e a incorporação da 3H-timidina para avaliar a síntese do DNA linfocitário. Nos dias zero e um, linfócitos e monócitos estavam aderidos às particulas de PGA. Não se observou indução de síntese do DNA dos linfócitos pelo PGA, no entanto, evidenciou-se uma expressão dos marcadores de ativação do antígeno do locus II do MHC e da IL-2 maior que o grupo controle negativo, porém, menor do que a observada na associação com a proteína derivada da tuberculina, sugerindo que o PGA apresentou-se imunologicamente inerte, causando apenas uma ativação linfocitária não específica.

BÖSTMAN et al. ${ }^{14}$ se apresentam como pesquisadores importantes do processo de degradação destes materiais. Em 1990, realizaram um estudo retrospectivo a partir da avaliação de 516 pacientes cujas fraturas e osteotomias foram fixadas com polímeros biodegradáveis PGA ou PLA/PGA, entre os anos de 1984 a 1988. Destes, 460 (89,1\%) evoluíram sem complicações. Quarenta e um 
pacientes desenvolveram edema localizado, sintomático, após dois a quatro meses das cirurgias, 7,5\% com fixações de PLA/PGA e 8,0\% de PGA. As drenagens cirúrgicas e os debridamentos possibilitaram a coleta de material para análise, que foi comparado aos espécimes obtidos dos pacientes que não apresentaram intercorrências, porém, não conseguiram sucesso mecânico das fixações. As tomografias computadorizadas realizadas em alguns pacientes após 12 semanas, apresentaram área radiolúcida aumentada ao redor dos implantes, tanto nos pacientes sintomáticos, quanto nos demais. Duas ou mais bactérias foram encontradas no exsudato colhido. Microscopicamente, observou-se um quadro em comum nos materiais coletados em ambas as situações, com uma exuberante infiltração por macrófagos e células gigantes tipo corpo estranho associadas aos fragmentos do material, além de neutrófilos e linfócitos. À medida que o tempo avançava, o processo inflamatório diminuía, até o desaparecimento do material reabsorvível aos 18 meses. 
No ano seguinte, BÖSTMAN ${ }^{12}$ realizou estudo individual, onde investigou o processo de degradação dos materiais de fixação absorvíveis por meio da avaliação radiográfica de 282 pacientes que tiveram fraturas do maléolo lateral ou bimaleolares fixadas com pinos de PGA. Estes pacientes foram divididos em dois grupos: o primeiro abrangendo 50 pacientes que não apresentaram problemas pós-operatórios durante o estudo; e o segundo, contendo 17 indivíduos cujo curso clínico foi complicado por alterações locais. Os pacientes do segundo grupo apresentaram inflamação repentina no calcanhar após dois a quatro meses após as cirurgias, resultando em fístula cutânea que liberava um exsudato com remanescentes do implante em degradação persistindo por quatro semanas. O quadro microscópico dos espécimes removidos destes pacientes revelou uma reação local tipo corpo estranho. Os exames radiográficos de 34 pacientes mostrou, a partir da sexta semana, a presença de áreas osteolíticas nos canais dos implantes, com dimensões que variaram entre 5 a $25 \mathrm{~mm}$. A partir do sexto mês, estas áreas radiolúcidas começavam a diminuir, desaparecendo após um ano. As áreas osteolíticas ocorreram com maior freqüência em pacientes com reação tipo corpo estranho, 14 
de 17, do que naqueles que não apresentaram intercorrências pós-operatórias, 20 de 50 pacientes.

Já em 1992, BÖSTMAN et al. ${ }^{15}$, avaliaram o processo de degradação de parafusos reabsorvíveis de PGA na fixação de osteotomias em 27 coelhos Nova Zelândia para estudo microscópico, morfométrico e radiográfico. Destes animais, cinco foram também submetidos a testes mecânicos. Para tanto, realizou-se uma osteotomia transcondilar transversa no osso medular, 8 a $10 \mathrm{~mm}$ proximal em nível da articulação do joelho em uma das pernas do animal. Reduziu-se a osteotomia e fixou-se com parafuso de PGA de 4,5mm de diâmetro por 30mm de comprimento. O lado oposto foi utilizado como controle, recebendo o mesmo parafuso, porém, sem realizar a osteotomia. No teste mecânico, a média de pico de força para falha foi de $95,0 \pm 64,8 \mathrm{~N}$ para os espécimes referentes às regiões osteotomizadas, e de $257,0 \pm 105,3 \mathrm{~N}$ para o lado controle. Microscopicamente, o parafuso ainda permanecia intacto após três semanas. Após seis semanas, a interface tecidoparafuso era evidente, com ocasional infiltração de tecido conjuntivo fibroso no 
polímero. Doze semanas depois, observaram-se áreas de erosão do parafuso, e sua substituição por tecido conjuntivo fibroso. No período final de degradação do material, evidenciou-se a presença de leucócitos mononucleares e células gigantes tipo corpo estranho associadas a partículas do polímero. Após 36 semanas não mais se visualizava o material, e sim tecido conjuntivo fibroso preenchendo a área previamente ocupada pelo parafuso.

As características clínicas e microscópicas das reações teciduais tardias a materiais de fixação reabsorvíveis também foram demonstradas por BERGSMA et al. ${ }^{9}$, em 1993. No período entre os anos de 1986 e 1988, dez pacientes com fraturas instáveis do complexo zigomático foram tratadas com placas e parafusos de PLA. Após três anos, quatro pacientes retornaram devido a um edema na região referente aos materiais reabsorvíveis. Em novo procedimento cirúrgico, amostras dos orifícios deixados pelos parafusos foram removidas para análise. À microscopia de luz, foi possível observar reação tipo corpo estranho sem sinais de inflamação aguda. Nas áreas centrais, remanescentes das placas e parafusos de PLA foram observados, 
circundados por denso tecido conjuntivo fibroso. A microscopia eletrônica revelou grande quantidade de material lamelar ou cristalóide no interior de macrófagos e de células gigantes multinucleadas. Os espaços dos parafusos estavam preenchidos por osso lamelar, cobertos por uma fina camada de tecido conjuntivo contendo PLA. AGRAWAL; ATHANASIOU², em 1997, mostraram-se preocupados com os resultados apresentados na literatura referentes ao uso dos materiais de fixação reabsorvíveis, uma vez que na maioria das casuísticas relatadas observaram-se quadros de inflamação, osteólise e formação de fístulas assépticas. Pela ausência de evidente contaminação dos materiais ou de infecção, e por suas ocorrências tardias, sugeriu-se a possibilidade destes eventos estarem associados à própria reação tecidual aos produtos da degradação destes materiais e ao pH local. Para impedir ou minimizar estes efeitos, estes autores incorporaram três agentes tampões a implantes de PLA/PGA (50:50), sendo estes o carbonato de cálcio, o bicarbonato de sódio e cálcio hidroxiapatita. Noventa e seis espécimes foram fabricados, divididos em quatro grupos de 24 espécimes, sendo um grupo controle e três 
experimentais. Os espécimes eram pesados e imersos em água destilada a 37\%.

Cada grupo foi dividido para serem testados nos períodos de zero, três, seis e nove semanas, quando eram submetidos à análise de massa, peso molecular, propriedades mecânicas e morfologia de superfície. O grupo controle manteve o pH neutro até 24 dias, quando então decrescia em um índice de 0,23 por dia, estabilizando-se por volta de 3,0. Os espécimes de cálcio hidroxiapatita alcançaram $\mathrm{pH} 4,3$ ao final do período. O bicarbonato de sódio iniciou com $\mathrm{pH} 8,0$, diminuindo a partir da quinta semana para 4,5. O carbonato de cálcio mostrou a menor variação, entre 7,4 e 6,3

BÖSTMAN; PIHLAJAMÄKI ${ }^{13}$, no ano de 2000, avaliaram 2.528 pacientes, tratados de fraturas variadas com parafusos, pinos e outros materiais de fixação absorvíveis feitos de PGA ou PLA, a fim de observarem as reações teciduais frente a estes materiais. Um total de 108 indivíduos (4,3\%) desenvolveu reação tipo corpo estranho aos materiais. Apenas as reações que apresentavam a formação de uma pápula eritematosa, causando sintomatologia dolorosa, ou ainda a presença de 
fístula, foram consideradas no estudo. Quando o material apresentava-se colorido, o risco de reação aumentava. Também a morfologia do material influenciou o índice de reações, apresentando-se maior quando associadas a parafusos serrilhados. $\mathrm{O}$ período médio para o início dos sinais de reação tipo corpo estranho foi de 79 dias, com o aparecimento repentino de um edema flutuante, eritematoso, que se não fosse imediatamente aspirado ou incisado, drenava em poucos dias um líquido livre de bactérias, por até seis semanas. Os exames radiográficos mostraram área de osteólise ao redor dos implantes em 62 pacientes. Em quatro, houve evolução para uma severa osteoartrite. Microscopicamente, viram-se fragmentos birrefringentes do material associados a leucócitos mononucleares e células gigantes tipo corpo estranho. Dentre os pacientes tratados com materiais de PLA, apenas um desenvolveu reação semelhante. 


\section{PROPOSIÇÃO}

Neste estudo, realizado em áreas de reconstrução alveolar com enxertos ósseos autógenos, propõe-se, através de microscopia óptica de luz, analisar:

- o comportamento dos tecidos frente à utilização de parafusos de fixação reabsorvíveis, à base de PLA/PGA. Procurar-se-á, por meio de análise descritiva, comparar as áreas onde se empregaram estas fixações, com outras que receberam parafusos convencionais de titânio. 


\section{MATERIAL E MÉTODOS}

\subsection{Seleção e preparo dos pacientes}

Sete pacientes, três mulheres e quatro homens, com idades variando entre 22 e 56 anos (Tabela 1), média de 39 anos, foram selecionados da clínica do Ambulatório de Implantodontia do Curso de Odontologia da Universidade do Sagrado Coração, Bauru, SP, apresentando defeitos ósseos maxilares e mandibulares em regiões desdentadas, a serem reconstruídas com enxertos ósseos autógenos, para posterior reabilitação com implantes osteointegrados. Os defeitos tratados correspondiam às classes IV, V e VI, segundo classificação de CAWOOD; HOWEL $^{19}, 1988$, apresentando deficiência de espessura e/ou altura óssea constatados pelos exames radiográficos e avaliação clínica.

A participação dos pacientes neste estudo foi de livre e espontânea vontade, após esclarecimento dos procedimentos e aceitação do termo de concordância, bem como o parecer favorável do Comitê de Ética (Anexo 1). 
Tabela 1 - Caracterização da Amostra

N. Nome Sexo Idade Área Reconstruída Região Zona Doadora Tipo de Anestesia

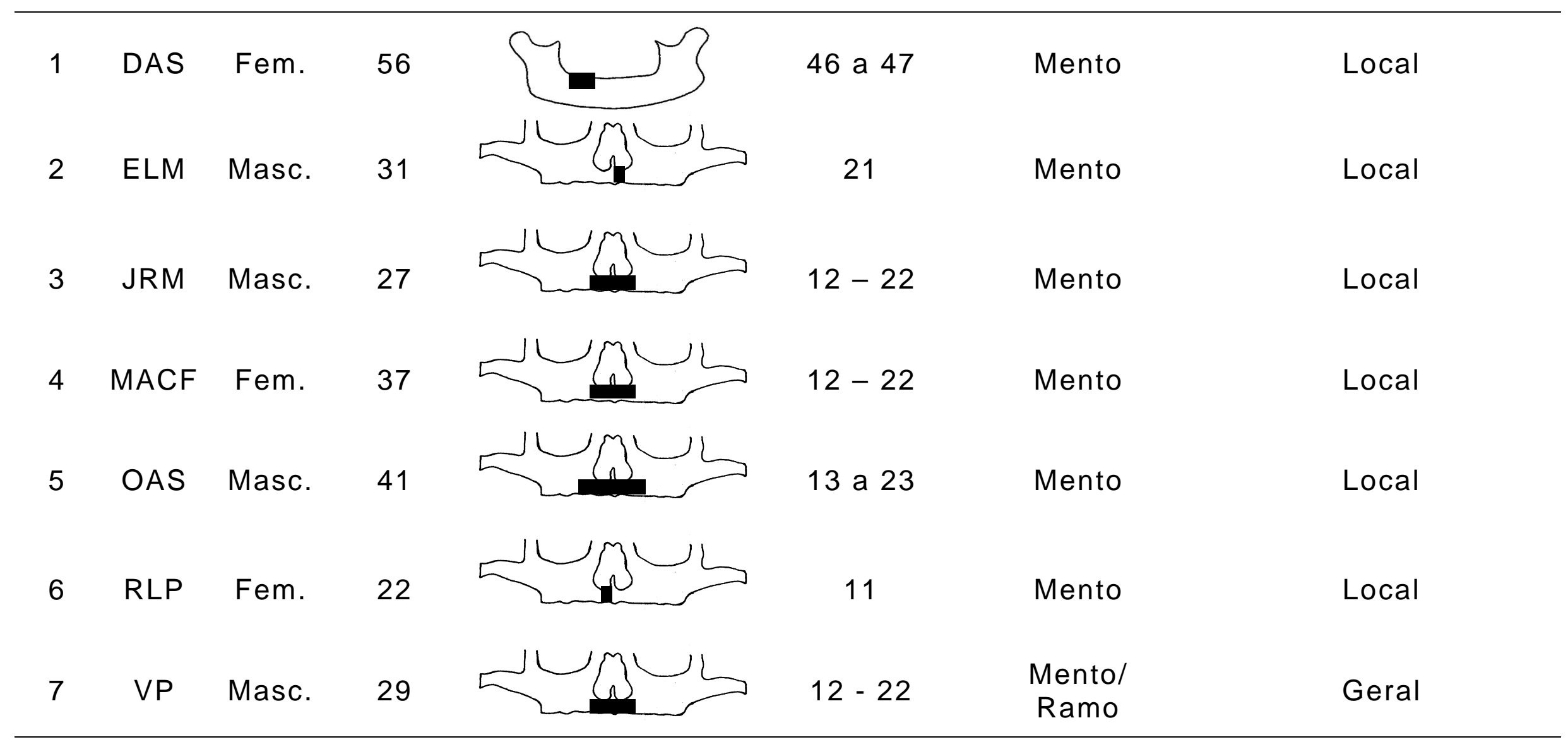


Todos os pacientes foram submetidos à anamnese detalhada, e os exames laboratoriais foram requeridos quando se declarava ou se suspeitava de alterações sistêmicas.

\subsection{Procedimentos cirúrgicos e obtenção dos espécimes}

A maioria dos procedimentos cirúrgicos para a realização dos enxertos ósseos foi realizada em ambiente ambulatorial, com anestesia local. Apenas um paciente foi submetido à anestesia geral em virtude da extensão da área a ser reconstruída e de seu perfil psicológico. Devido aos tipos de defeitos ósseos observados optaram-se pelas técnicas onlay e veneer com enxertos ósseos em bloco, provenientes das regiões de sínfise, corpo e ramo mandibulares.

A exposição do leito receptor foi feita através de incisões praticadas na crista alveolar, estendendo-se pelo sulco gengival dos dentes vizinhos, quando estes estavam presentes, evitando-se o uso de incisões verticais ou oblíquas. A superfície óssea do defeito foi exposta às custas de amplos descolamentos mucoperiostais, 
permitindo a visualização da dimensão do enxerto necessário. Realizado este tempo cirúrgico, partiu-se para o acesso à região doadora. Para a obtenção dos enxertos de mento, seguiram-se os procedimentos técnicos descritos por TULER; NARY $\mathrm{FILHO}^{95}, 1999$, procedendo-se a incisão em mucosa labial e divulsão por planos até a exposição da superfície óssea da sínfise mandibular. Para a osteotomia, empregouse serra oscilatória pneumática* após prévia demarcação da área a ser removida com brocas esféricas de aço número $1 / 2$ sob abundante irrigação com soro fisiológico. Complementando a ação da serra, com o auxílio de cinzéis e martelo obteve-se o bloco de enxerto corticomedular (Figuras 2 e 3).

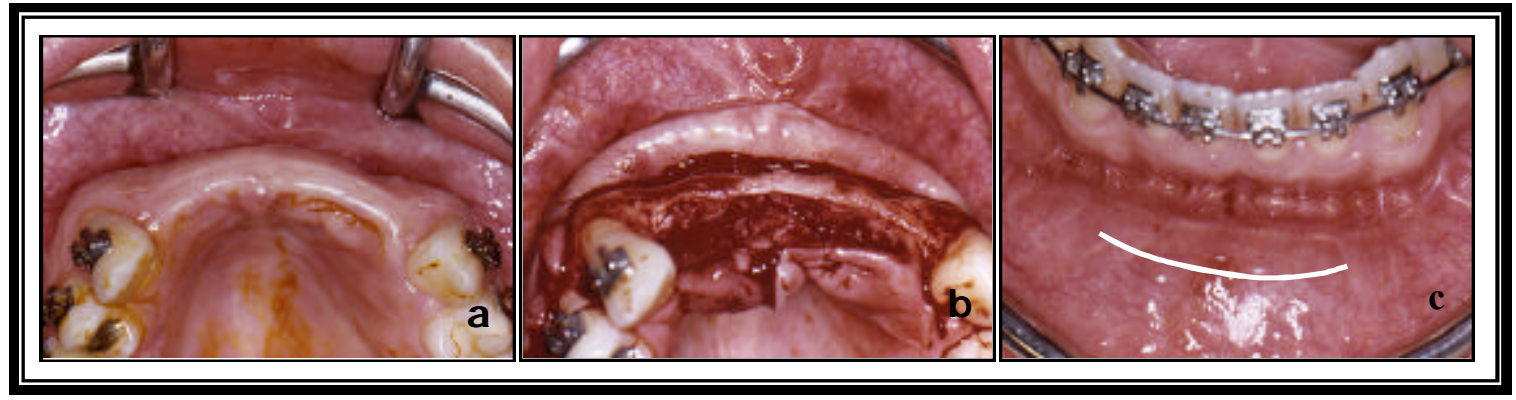

Figura 2 - a) Aspecto clínico da região anterior de maxila a ser reconstruída; b) exposição da região receptora, exibindo o defeito ósseo; c) linha de incisão em mucosa labial da área doadora

\footnotetext{
* Microdrive plus e serra oscilante 6000 osc./min., Synthes - STRATEC Medical, Suíça
} 


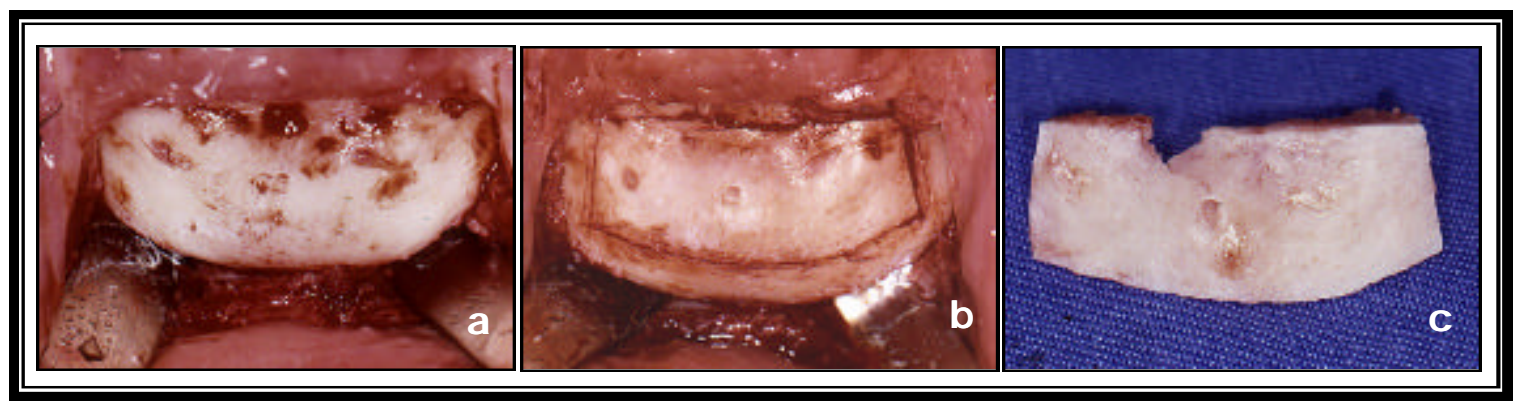

Figura 3 - a) Divulsão por planos e exposição da área doadora; b) ostectomia realizada com serra pneumática; c) bloco ósseo removido

Os cuidados com a ferida cirúrgica incluíram irrigação abundante com soro fisiológico, sutura por planos e reinserção muscular com fios de sutura sintéticos de poliglactina $910^{*}$ e poliglecaprone $25^{* *}$.

Quando se abordou a região de ramo para obtenção de enxerto, incisão mucoperiostal foi executada sobre a linha oblíqua, permitindo amplo descolamento e exposição da área do corpo, ramo e processo mandibular. Neste acesso, não foi empregada serra pneumática, apenas brocas de aço tronco-cônicas 699 e discos diamantados com raio de $0,8 \mathrm{~mm}$.

\footnotetext{
* Vycril - Ethicon, São José dos Campos, Brasil

** Monocryl - Ethicon, São José dos Campos, Brasil
} 
Incluiu a amostra, um paciente que recebeu enxerto de ramo e corpo mandibulares, associados ao mento, uma vez que toda a análise foi feita neste último.

Removidos os blocos das respectivas regiões doadoras, estes foram mantidos em solução salina a $9 \%$ até que fossem utilizados. Em seguida, realizou-se a adaptação do enxerto ao leito receptor empregando-se alveolótomo e brocas de desgaste multilaminadas. Procurou-se manter a área medular do enxerto sobre o defeito para facilitar sua adaptação e facilitar sua revascularização. A porção cortical correspondeu ao aspecto externo da reconstrução, se prestando, inclusive, para a proporcionar maior efetividade à fixação. Com os blocos, devolveu-se a anatomia da região, incluindo uma sobrecorreção, prevendo-se o fenômeno de reabsorção óssea pós-operatória. A fixação dos blocos foi realizada com parafusos corticais de titânio* de $1,5 \mathrm{~mm}$ e $2 \mathrm{~mm}$ de diâmetro com comprimentos variáveis (Figura 4).

\footnotetext{
* Cortical Titanium screw MF compact 1,5 e 2,0 - Synthes, STRATEC Medial, Suiça
} 


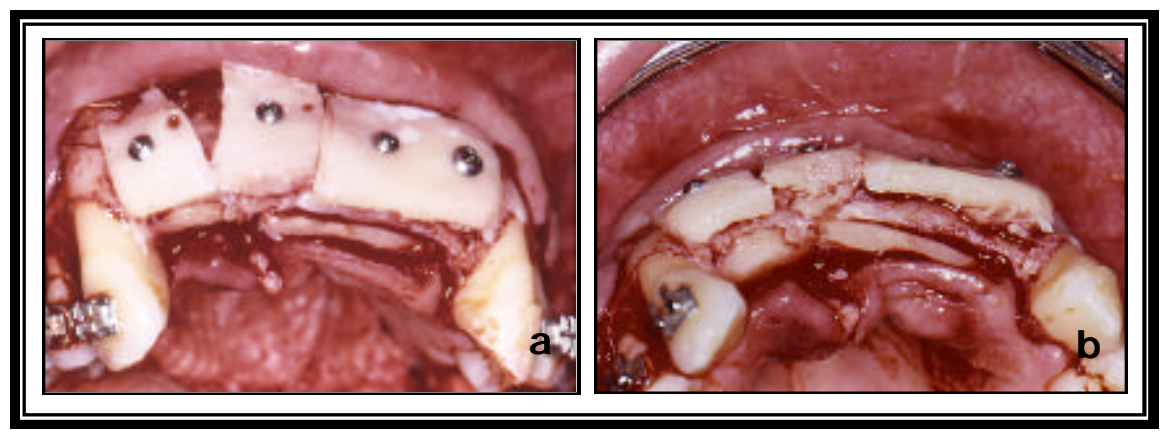

Figura 4 - Fixação dos blocos ósseos ao leito receptor com parafusos de fixação de titânio, em a) vista frontal e b) vista oclusal

Após adequada fixação do enxerto, foram instalados os parafusos de teste.

Em regiões onde não se intencionava a instalação posterior dos implantes osteointegrados, foram colocados os parafusos reabsorvíveis. Da mesma forma, foram selecionadas áreas onde a remoção dos mesmos, em períodos subseqüentes, juntamente com um faixa de tecido ósseo circundante, não comprometesse a arquitetura e estética da reconstrução.

Os parafusos de teste, compostos de ácido poli-L-láctico (PLA) e ácido poliglicólico (PGA) na proporção de $82: 18^{* *}$, possuíam 1,5mm de diâmetro por 3mm de comprimento. Para seu parafusamento, empregou-se broca de $1,1 \mathrm{~mm}$ de diâmetro e uma chave especial que permitiu sua inserção e rosqueamento até o

\footnotetext{
${ }^{* *}$ LactoSorb, Walter Lorenz Surgical - Jacksonville, E.U.A.
} 
limite de sua profundidade. Nesta altura, devido à área de fragilidade localizada ao redor de sua cabeça, havia a fratura intencional que separava o parafuso da extensão de inserção (Figura 5).

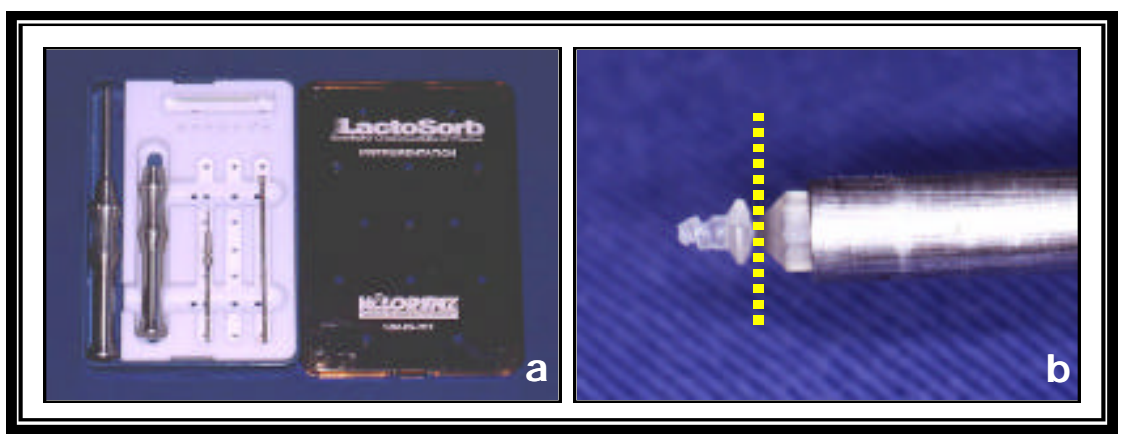

Figura 5 - Material de fixação LactoSorb. a) Chaves e brocas específicas para manipulação do material reabsorvível; b) chave para rosqueamento do parafuso reabsorvível; a linha pontilhada indica a região de fratura da extensão do parafuso

Em outra extremidade, também distante da região das instalações dos implantes, inseriu-se o parafuso de titânio* (Figura 6), apresentando as mesmas dimensões do absorvível, constituindo o grupo controle. Nestes casos, as perfurações seguiram a rotina dos parafusos empregados para fixação de enxertos.

\footnotetext{
* Walter Lorenz Surgical - Jacksonville, E.U.A.
} 


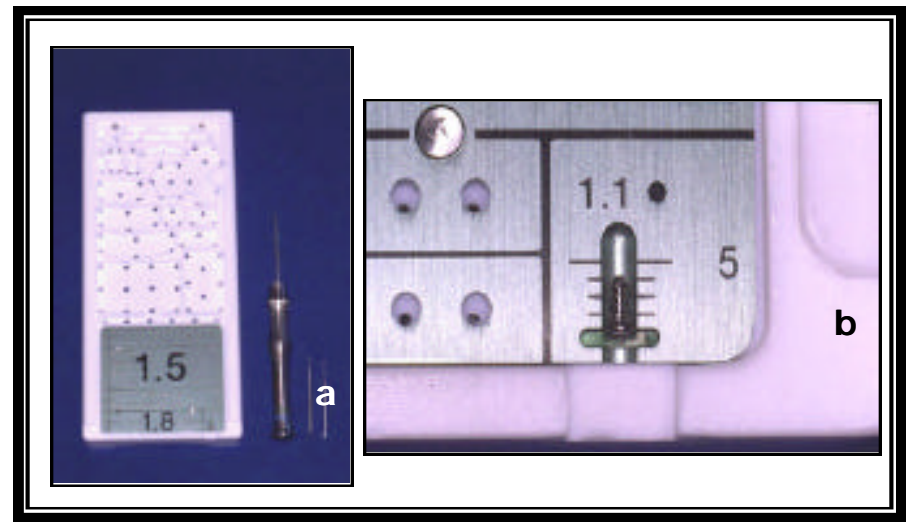

Figura 6 - Material de fixação de titânio. a) Chave e brocas específicas para inserção do material; b) parafuso de titânio do sistema 1.5

As fixações dos parafusos do grupo experimental e controle foram feitas somente nos enxertos removidos do mento (Figura 7). Quatro pacientes receberam um parafuso de cada material; os outros três pacientes receberam dois parafusos de cada material, totalizando dez parafusos reabsorvíveis e dez de titânio. Neste momento, regularizações adicionais foram executadas, finalizando a etapa de reconstrução.

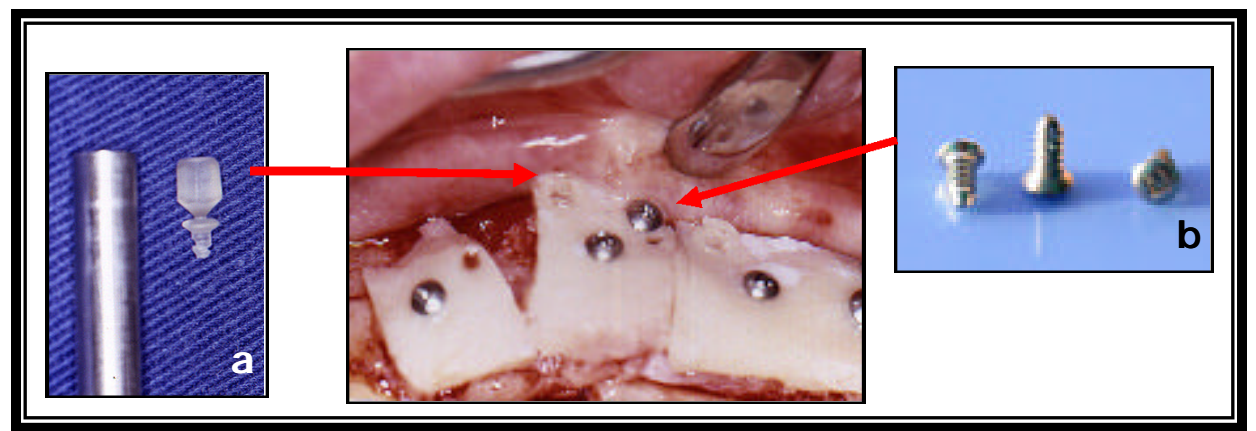

Figura 7 - Inserção dos parafusos de teste nos blocos ósseos: a) reabsorvível e b) de titânio 
Os espaços vazios, onde não se obteve contato do enxerto com o leito receptor, foram preenchidos com osso particulado resultante do material excedido do preparo do bloco, triturado com aparelho específico (Figura 8a). Nenhum cuidado foi observado com relação à ativação do leito receptor, como por exemplo, a execução de perfurações. A cobertura mucosa do enxerto foi conseguida às expensas de grande divulsão submucosa das regiões vizinhas, vestíbulo e mucosa labial com preservação do periósteo (Figura 8b).

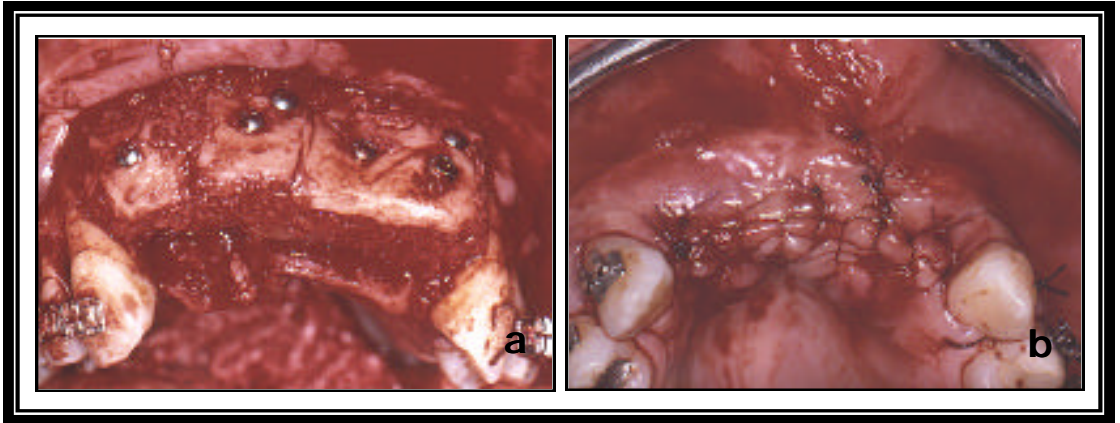

Figura 8 - a) Preenchimento dos espaços entre os fragmentos com osso triturado; b) cobertura mucosa e sutura

As suturas promoveram não somente a aproximação das bordas como também o aumento de contato das faces cruentas. Realizou-se curativo compressivo 
com fitas de micropore nas áreas doadora e receptora, para conferir maior conforto e para a contenção do edema.

Após os procedimentos cirúrgicos, os pacientes receberam as orientações básicas para este tipo de tratamento, evitando-se, em especial, o trauma devido ao uso de próteses sobre o local por período mínimo de 15 dias. Todos os pacientes fizeram uso de 1,5g de amoxicilina ao dia, durante sete dias, além de analgésico, $1 \mathrm{~g}$ de dipirona 4 vezes ao dia. Não se empregaram antiinflamatórios, em nenhum dos casos.

O período aguardado para a instalação dos implantes osteointegrados foi de quatro meses, desde a cirurgia de reconstrução, conforme MATSUMOTO et al. ${ }^{59}$, 2002. Nesta ocasião, aproveitou-se o mesmo acesso cirúrgico para se realizar as biópsias referentes às áreas de inserção dos parafusos reabsorvíveis e de titânio. Para isto, utilizou-se brocas trefinas* apresentando diâmetro interno de 2,6mm, sob

\footnotetext{
* Ace Surgical Supply Co. - Brockton, E.U.A.
} 
abundante refrigeração, obtendo-se o parafuso e o osso adjacente em um só bloco, no caso dos parafusos reabsorvíveis (Figura 9).

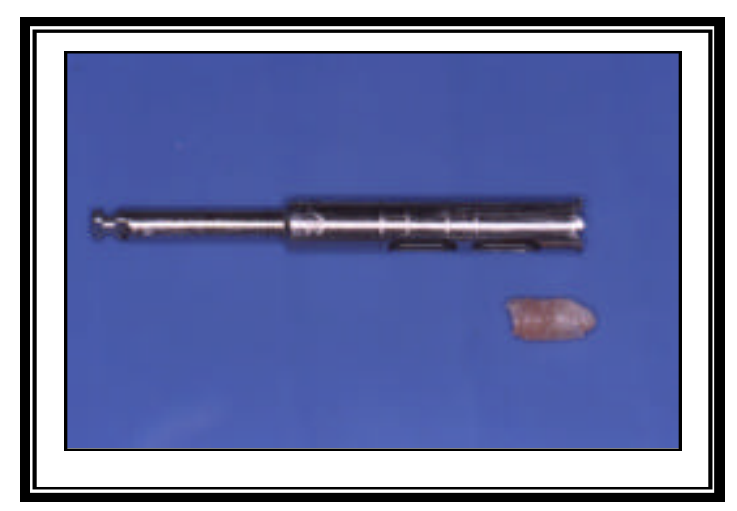

Figura 9 - Aspecto macroscópico do espécime removido das regiões ocupadas pelos parafusos de teste com tecido ósseo adjacente para análise da interface

Já os parafusos de titânio foram removidos com chave específica, para depois, proceder-se a biópsia com a mesma broca. Há de se destacar que, concomitantemente à remoção dos espécimes deste estudo, também foram removidos os parafusos de fixação dos enxertos para possibilitar a instalação dos implantes. A seqüência do tratamento reabilitador seguiu os procedimentos convencionais. 


\subsection{Preparo dos espécimes}

Os espécimes obtidos foram acondicionados em frascos individuais

identificados, contendo formol 10\% tamponado por um período mínimo de 48 horas, antes de serem desmineralizados em ácido etilenodiaminotetracético (EDTA) 10\%, tamponado com $\mathrm{pH} 7,0$, com trocas realizadas duas vezes por semana. O período de desmineralização variou de um a dois meses, até que os fragmentos alcançassem consistência borrachóide, não conferindo resistência ao corte do

micrótomo. As peças foram então lavadas em água corrente por 24 horas, desidratadas em álcool, diafanizadas em xilol e incluídas em parafina.

Obtiveram-se cortes semi-seriados de $6 \mu \mathrm{m}$ de espessura de cada bloco utilizando-se micrótomo rotatório elétrico Leica RM. Empregaram-se para a análise, os cortes centrais do espécime, onde a maior extensão seria representada, correspondendo ao diâmetro máximo do cilindro ósseo. As tiras foram colocadas em banho-maria, de onde foram retiradas e imediatamente dispostas por sobre a lâmina 
com albumina. As lâminas seguiram para a estufa e posteriormente para a desparafinização.

Os métodos de coloração empregados foram o da Hematoxilina-Eosina de Harris (HE) e Tricrômico de Mallory preconizados e registrados nos protocolos técnicos da Disciplina de Histologia do Curso de Odontologia da Universidade do Sagrado Coração.

\subsection{Análise microscópica morfológica descritiva}

A leitura das lâminas foi realizada com auxílio de microscópio Olympus CBA binocular, analisando-se o tecido adjacente aos parafusos quanto à presença de infiltrado inflamatório, formação de tecido conjuntivo fibroso, neoformação óssea, reabsorção óssea, reação tipo corpo estranho, ou ainda, de outros fenômenos que pudessem ser visualizados.

Os dados obtidos a partir da identificação dos fenômenos morfológicos foram registrados através de fotomicrografias, ilustrando a descrição microscópica. 
Estas foram obtidas a partir de aparelho Zeiss - Axioskope 2, da Disciplina de Patologia da Faculdade de Odontologia de Bauru (FOB-USP), utilizando-se filme Prolmage - Kodak, ISO 100. 


\section{5 - RESULTADOS}

Os resultados são apresentados descrevendo-se os aspectos microscópios encontrados nos dois grupos experimentais . Registraram-se os fenômenos morfológicos observados nos dois grupos em quadros previamente elaborados para esta finalidade (Anexos 2 e 3). A partir destes, procedeu-se à análise microscópica descritiva dos mesmos, ilustrada nas fotomicrografias.

5.1 Espécimes referentes aos enxertos ósseos fixados com parafusos de titânio

$\mathrm{Na}$ análise microscópica dos espécimes, observou-se fragmento ósseo apresentando área central ora vazia, ora preenchida por hemácias, referente ao lugar ocupado previamente pelo parafuso de titânio (Figura 10). Evidenciou-se tecido ósseo do tipo cortical adjacente à área previamente ocupada pelo parafuso, apresentando numerosos canais de Havers e osteoplastos ocupados, na maioria 
dos espécimes, por osteócitos, caracterizando, morfologicamente, sua viabilidade (Figura $11 \mathrm{a} ; \mathrm{b})$.

Em alguns fragmentos, pôde-se viabilizar revestimento parcial e irregular de endósteo, constituído, predominantemente, por células de revestimento (Figura 12 a; b). Em três espécimes observaram-se discretas áreas de tecido conjuntivo justaposto à superfície óssea, porém, na maioria dos espécimes, as superfícies ósseas encontravam-se livres de células ou de tecido fibroso. Células inflamatórias não foram visualizadas, bem como áreas de reabsorção óssea.

5.2 Espécimes referentes aos enxertos ósseos fixados com parafusos de PLA/PGA

$\mathrm{Na}$ análise microscópica dos espécimes, observou-se fragmento de tecido ósseo com área central referente à região ocupada pelo parafuso reabsorvível, preenchida por fragmentos irregulares birrefrigentes (Figura 13), decorrentes da persistência do material no período da biópsia, e pela influência dos procedimentos 
histotécnicos. Adjacente a esta região central notou-se, em nove dos espécimes analisados, apresença de faixa de tecido conjuntivo fibroso caracterizado por feixes de fibras colágenas dispostas paralelamente entre si, configurando aspecto capsular (Figura 14 a; b). Em três espécimes se evidenciaram eventuais leucócitos mononucleares no tecido conjuntivo interposto entre o parafuso e o osso (Figura 15 a; b). Leucócitos polimorfonucleares não foram visualizados. Em alguns fragmentos, observou-se a presença de células gigantes multinucleadas tipo corpo stranho, associadas aos parafusos rabsorvíveis (Figuras 16 a; b; 17 a; b).

Tecido ósseo do tipo cortical adjacente à área ocupada plo parafuso foi visualizado, constituído por canais de Havers lacunas prenchidas por osteócitos, indicando, morfologicamente, sua viabilidade do tecido. Evidenciou-se, ainda, a presença de camada endosteal constituída, predominantemente, por células de revestimento (Figura 18 a). No osso adjacente à faixa de fibrose, observou-se a presença de eventuais regiões com atividade clástica (Figura 18 b). 


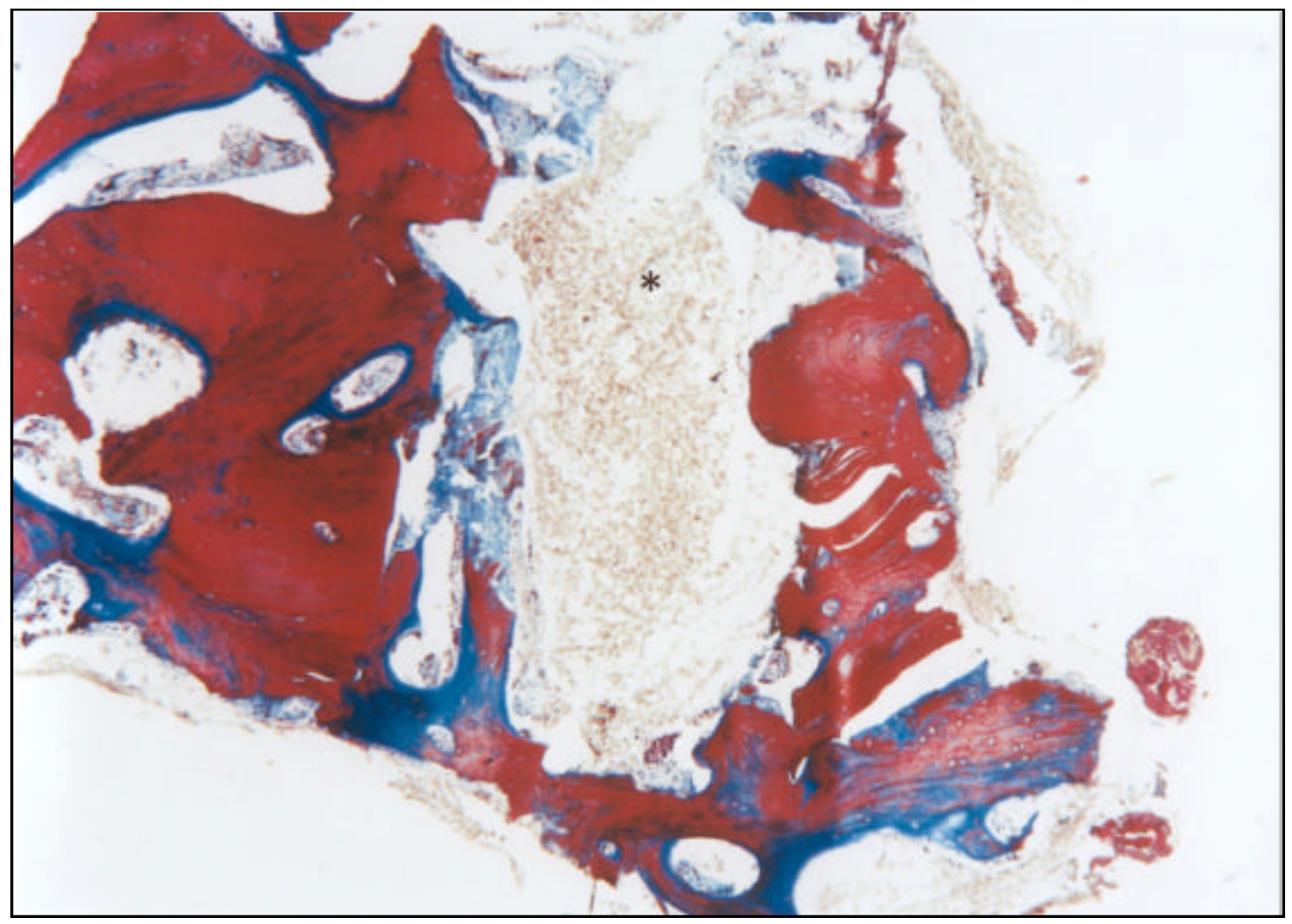

Figura 10 - Espécimes de grupo controle, evidenciando fragmento ósseo apresentando região central previamente ocupada pelo parafuso preenchida por hemácias $\left(^{*}\right)$. (Coloração Tricrômico de Mallory, aumento original:50x) 

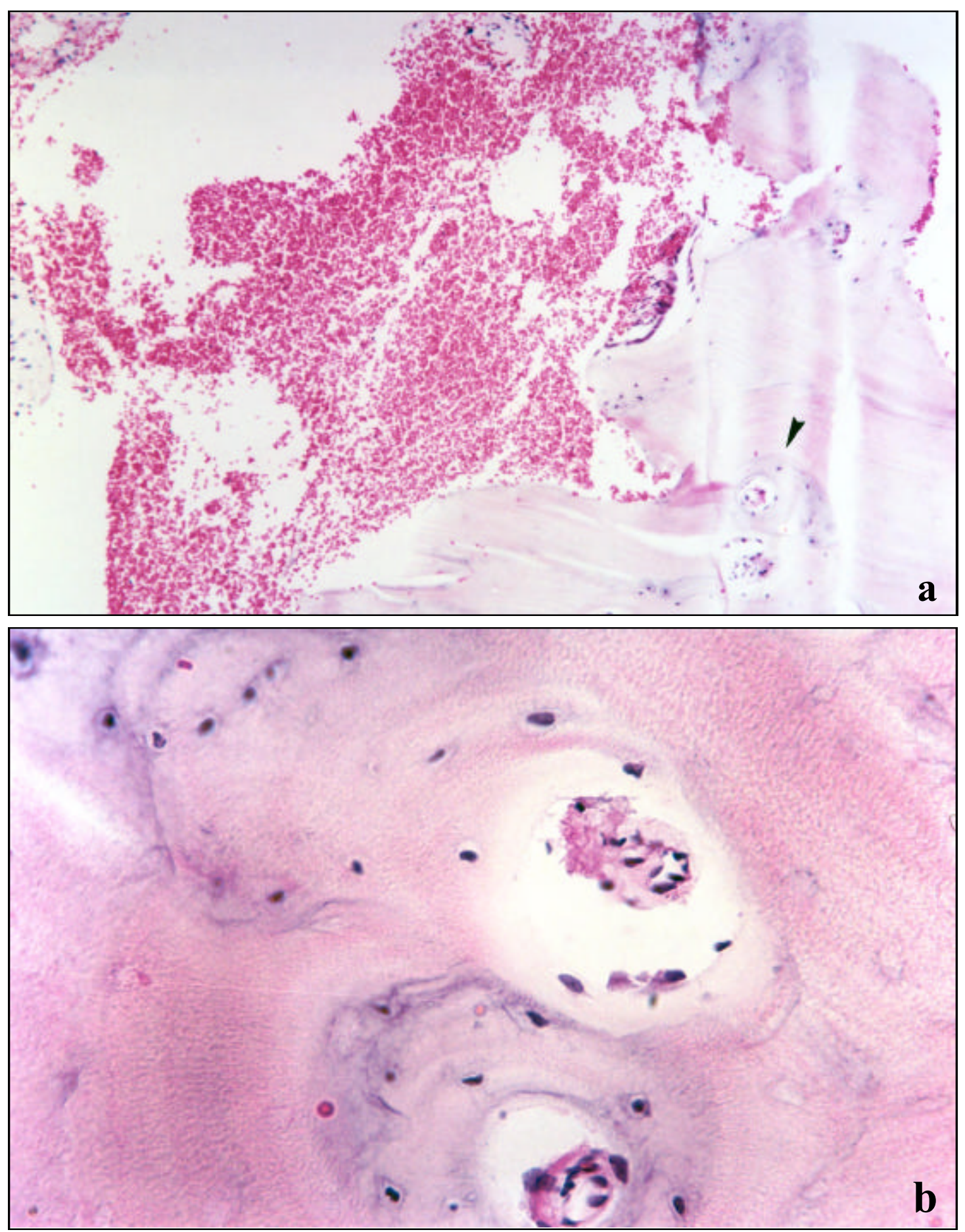

Figura 11 - Aspecto do tecido ósseo adjacente, do tipo cortical, constituído pelos canais de Havers (setas grandes). As lacunas ósseas apresentam-se preenchidas por osteócitos, caracterizando viabilidade morfológica do tecido (setas pequenas). (Coloração H.E.; aumento original: $a=50 x ; b=400 x$ ) 

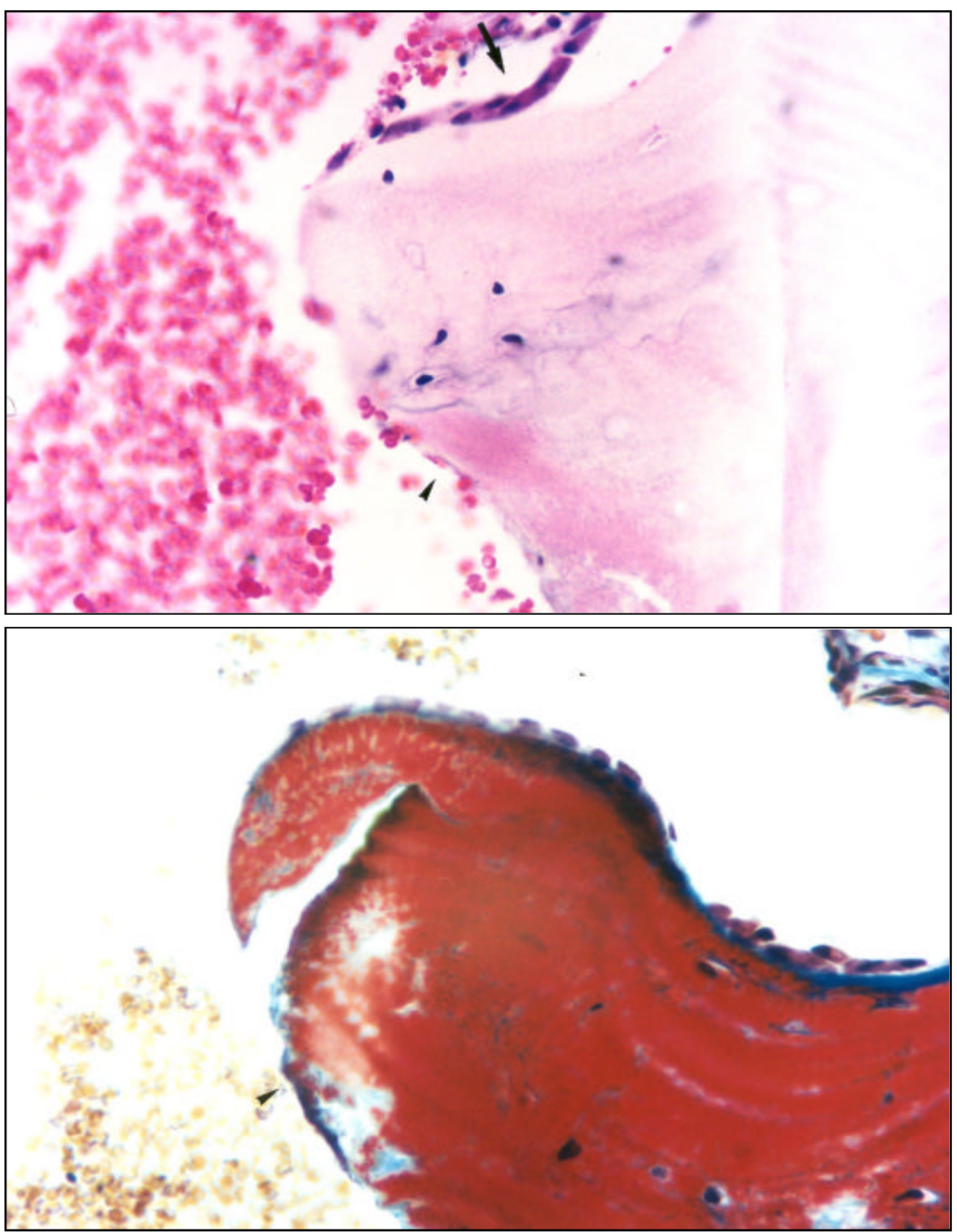

Figura 12 - Aspecto das superfícies ósseas, adjacentes à área ocupada pelo parafuso de titânio, mostrando ora ausência de células ou tecido conjuntivo (setas pequenas), ora células de revestimento (setas grandes). (Coloração H.E.; aumento original: $\mathrm{a}=400 \mathrm{x}$; coloração Tricrômico de Mallory; aumento original: $b=400 x)$ 


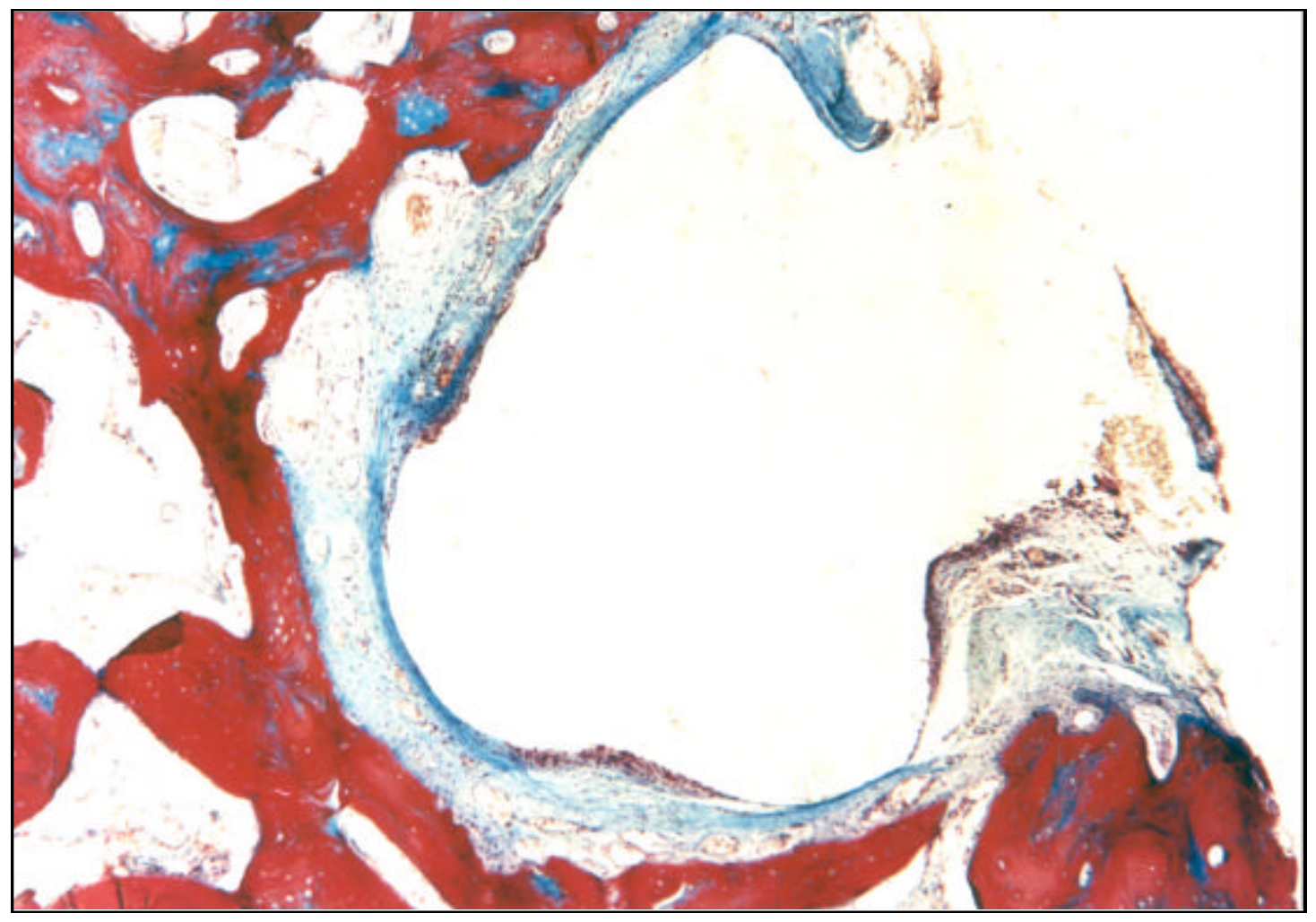

Figura 13 - Espécime referente ao parafuso de PLA/PGA, exibindo fragmento ósseo apresentando região central preenchida por framentos irregulares birrefringentes referentes à permanência do material reabsorvível $\left(^{*}\right)$. (Coloração Tricrômico de Mallory; aumento original 50x) 

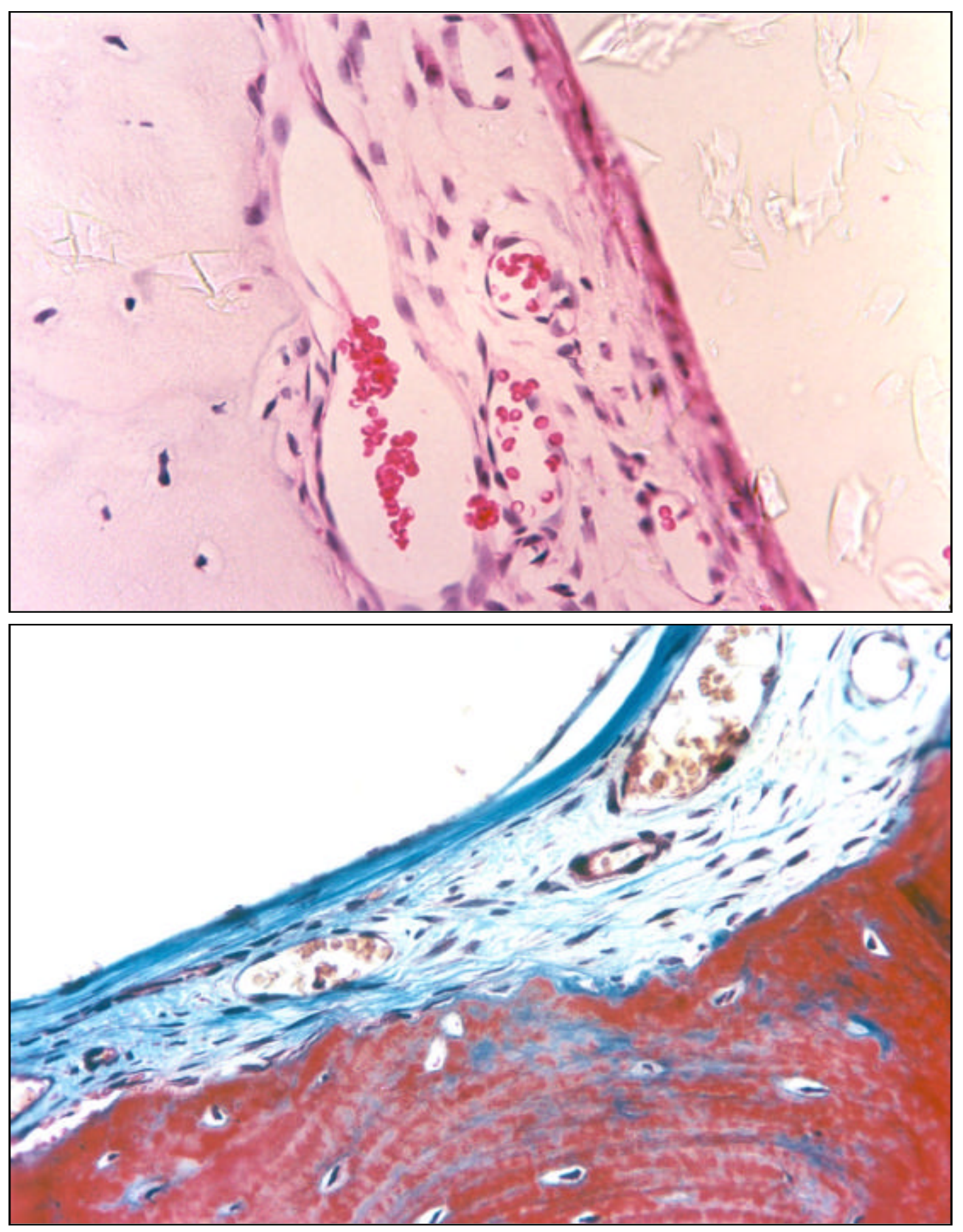

Figura 14 - Tecido conjuntivo fibroso interposto entre a região previamente ocupada pelo parafuso e o tecido ósseo adjacente, apresentando feixes de fibras colágenas organizados paralelamente entre si $(*)$. (Coloração H.E.; aumento original: $\mathrm{a}=$ 400x; coloração Tricrômico de Mallory; aumento original: $b=400 x$ ) 

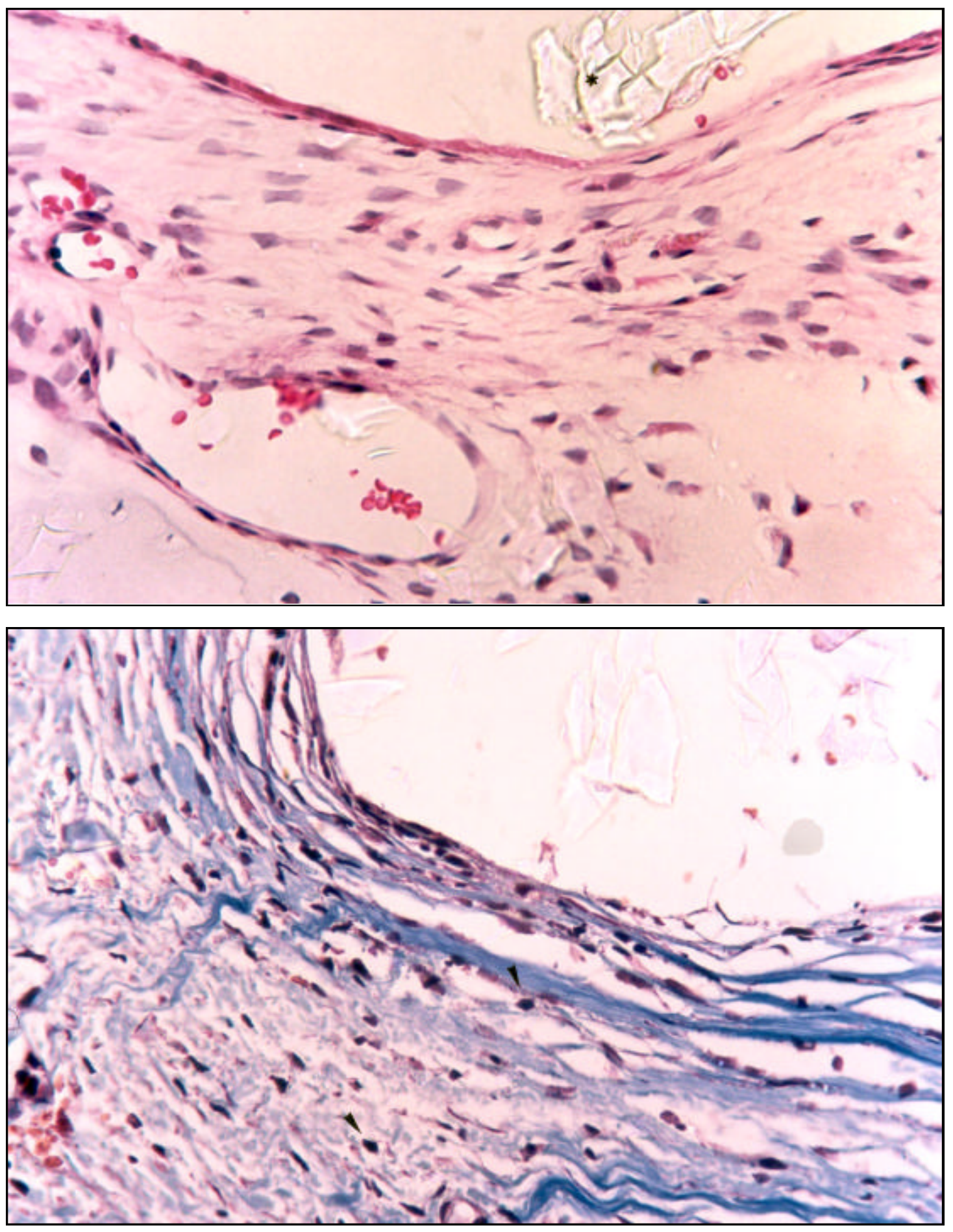

Figura 15 - Fragmentos irregulares birrefringentes referentes à fragmentação do material reabsorvível (*). Eventuais leucócitos mononucleares foram visualizados no tecido conjuntivo fibroso (setas). (Coloração H.E.; aumento original: a = 400x; coloração Tricrômico de Mallory; aumento original: $b=400 x$ ) 

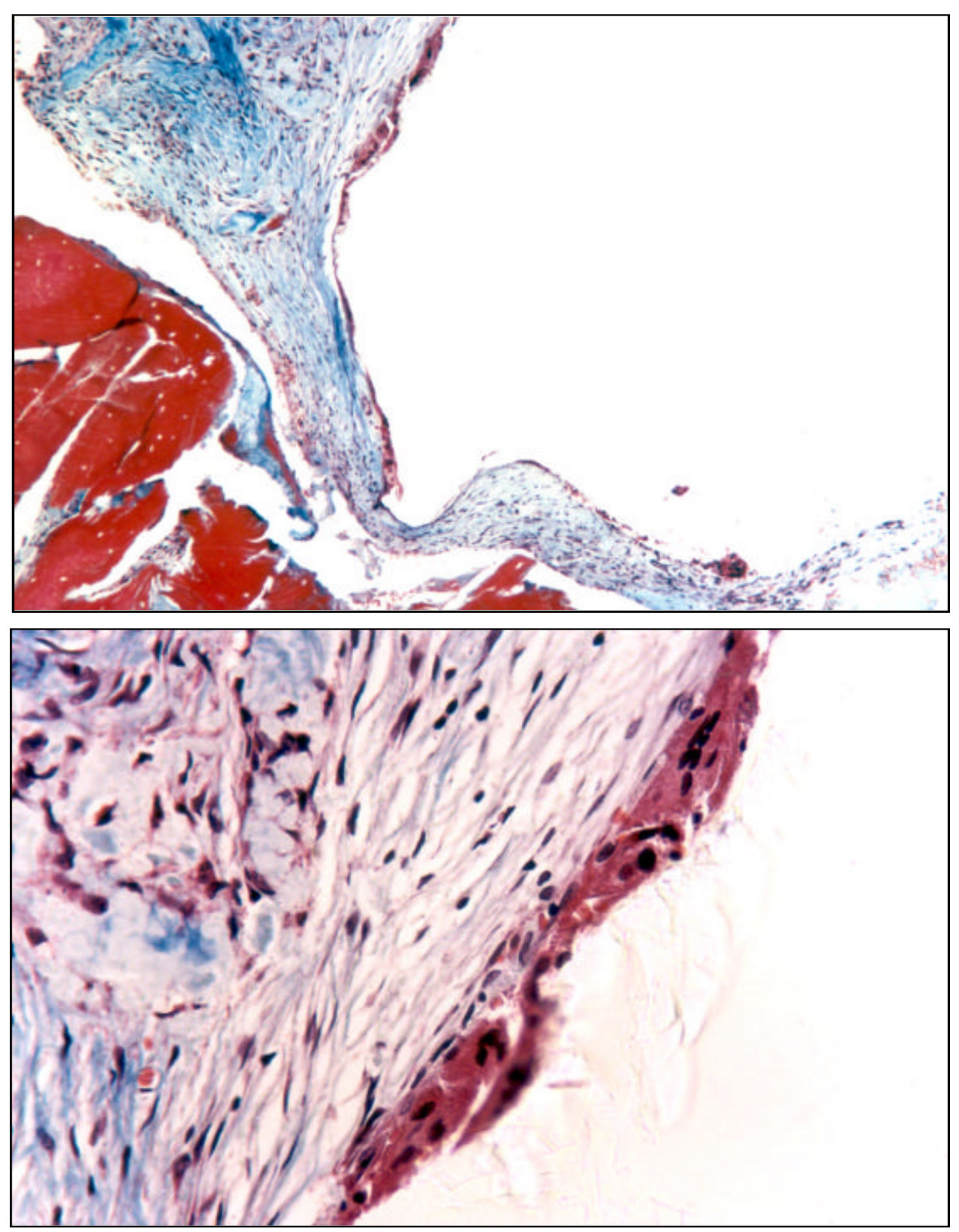

Figura 16 - Aspecto microscópico evidenciando células gigantes multinucleadas tipo corpo estranho associadas à presença do material reabsorvível (setas). (Coloração Tricrômico de Mallory; aumento original: $a=100 x ; b=400 x$ ) 

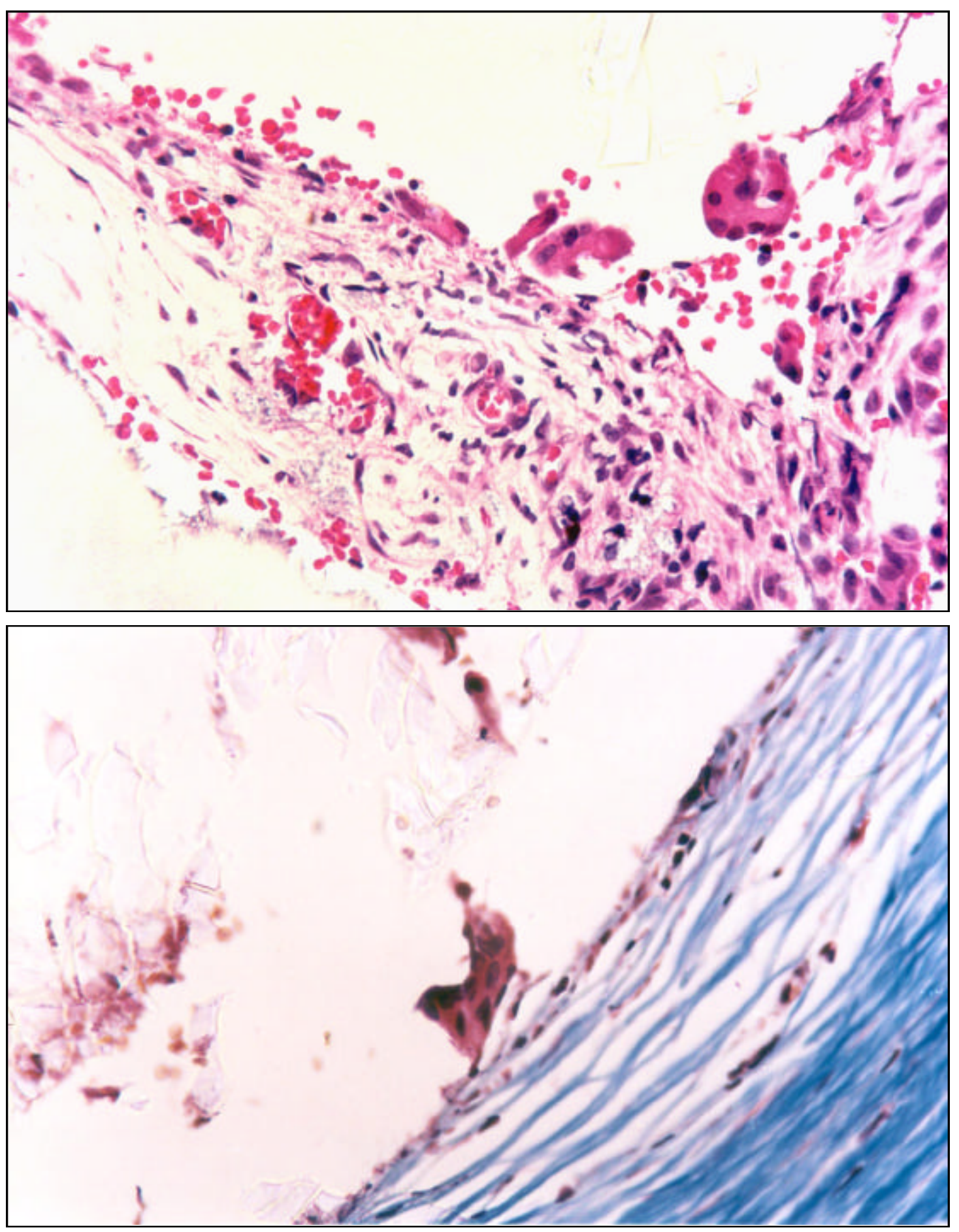

Figura 17 - Destaque das células gigantes multinucleadas tipo corpo estranho associadas aos fragmentos do parafuso reabsorvível (setas). (Coloração H.E.; aumento original: $a=400 x$; coloração Tricrômico de Mallory; aumento original: $b=400 x$ ) 

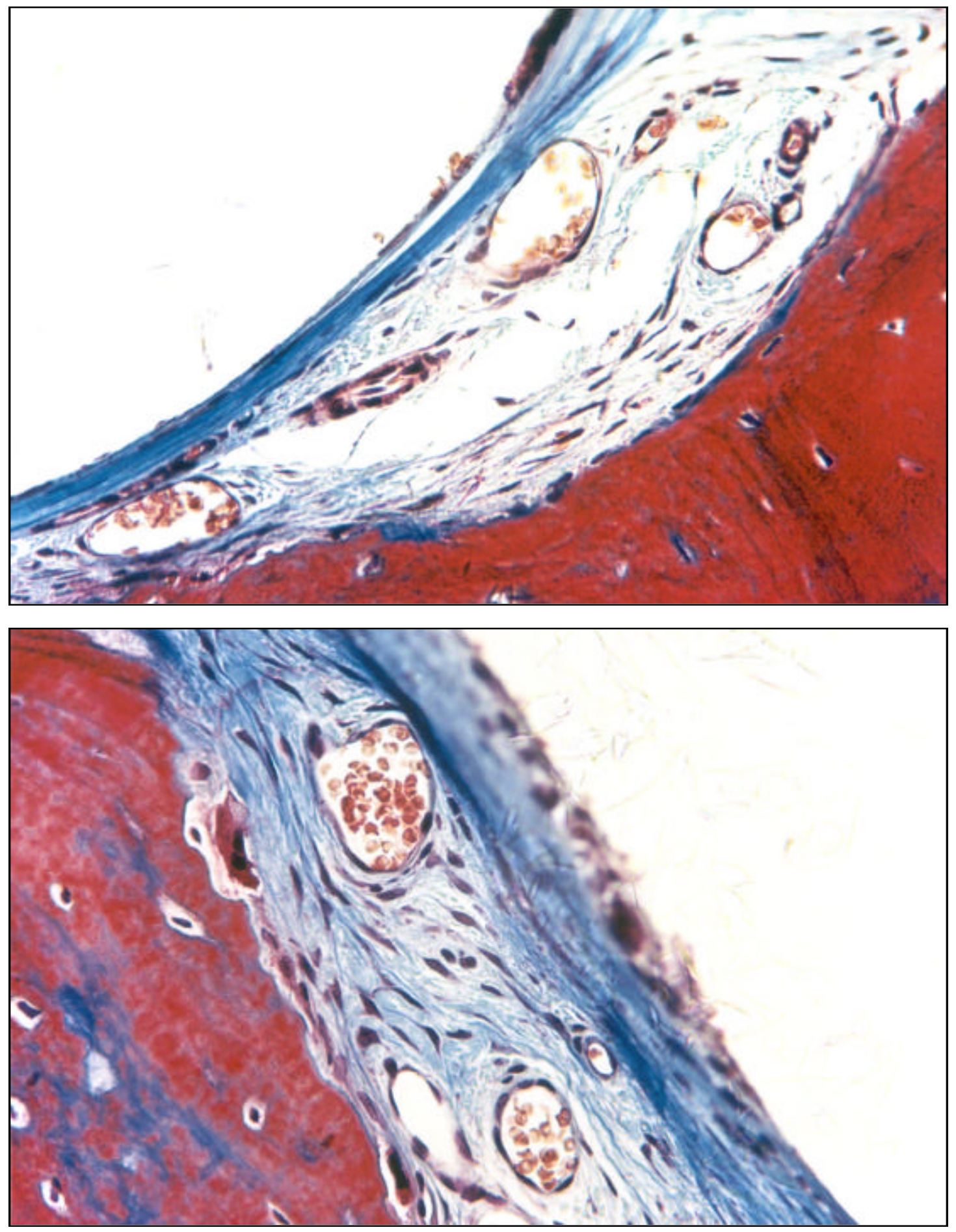

Figura 18 - Camada endosteal constituída por células de revestimento (setas pequenas). Presença de eventuais osteoclastos na superfície óssea (setas grandes). (Coloração Tricrômico de Mallory; aumento original: $a ; b=400 x$ ) 


\section{DISCUSSÃO}

A incansável busca por melhores técnicas e materiais que possam ser utilizados como substitutos do tecido ósseo revelam sua importância nas reabilitações protéticas implantossuportadas, tanto do ponto de vista estético quanto funcional. Todo o avanço no âmbito da bioengenharia e o conhecido comportamento dos implantes aloplásticos ${ }^{3,18,70}$ parecem ser afrontados com a insistente utilização dos enxertos ósseos autógenos, os quais dispõem os pacientes a um procedimento cirúrgico adicional e à morbidade inerente a cada área doadora ${ }^{40,44,50,66}$.

Esta atitude se justifica pelos resultados obtidos e amplamente divulgados na literatura pertinente, que revelam a superioridade dos enxertos autógenos pelas suas características osteoindutora, osteocondutora, e conseqüentemente, osteogênica, durante o processo de incorporação. Além disto, nesta condição, inexiste o risco de atividade imunogênica ${ }^{7,18,21,23}$. 
Há algumas décadas, considerava-se a origem embriológica do osso a ser transferido para outras áreas como sendo o fator determinante no processo de incorporação e sobrevivência do mesmo ${ }^{5,38,48,99}$. Sabe-se, atualmente, que independente da origem, a morfologia óssea, é na verdade, a responsável pelas diferenças nos padrões de reparação, não somente pelas características arquiteturais, mas também por sua constituição ${ }^{71,72}$. A partir do osso maduro torna-se impossível distinguir, por quaisquer análises, o tipo de ossificação que o originou. No entanto, se observam diferenças nos constituintes bioquímicos dos ossos cortical e medular que vão influenciar o reparo. No medular, predomina o contingente celular, gerador de fatores de crescimentos responsáveis pela osteogênese. O cortical, por sua vez, constitui a fonte primária de proteínas ósseas morfogenéticas (BMP), com capacidade osteoindutoras ${ }^{23}$.

Investigações comparativas sobre os padrões de revascularização dos enxertos endocondrais e intramembranosos, ou medulares e corticomedulares, revelam um processo mais precoce nos corticalizados, acelerando a incorporação 
dos fragmentos ao leito receptor, contribuindo, desta maneira, para uma melhor manutenção do volume obtido com a reconstrução ${ }^{48}$.

Por estes motivos, a fim de se obter qualidade e previsibilidade de comportamento clínico busca-se, sempre que possível, zonas doadoras como a calvária e a mandíbula na reconstrução dos rebordos alveolares. Esta última oferece ainda a vantagem da possibilidade de realização do procedimento em ambiente ambulatorial, favorecendo muito a decisão do paciente $8^{8,27,35,62,65,66}$. Sabe-se que os implantes osteointegráveis quando instalados em regiões de rebordo reconstruídas com enxertos ósseos autógenos, particulado ou em bloco, alcançam índices de sucesso considerados satisfatórios ${ }^{60,80,81,94}$, e, especificamente quando utilizados ossos mais corticalizados, estes índices tendem a ser ainda mais altos, como confirmado por autores como SCHLIEPHAKE; NEUKAM; WICHMANN ${ }^{83}$, 1997; SETHI; KAUS ${ }^{85}, 2001$.

Neste tipo de tratamento, pode-se optar pela instalação dos implantes osteointegráveis imediatamente ao procedimento de enxertia, ou após acontecer o 
processo de reparo junto ao leito receptor, com maior índice de sucesso nesta última situação ${ }^{16,52,94}$.

Os pacientes participantes do presente trabalho apresentavam defeitos classe IV, V e VI, seguindo a classificação de CAWOOD; HOWEL ${ }^{19}$, 1988. Apesar da anatomia insatisfatória dos rebordos, as áreas desdentadas a serem reconstruídas permitiram a utilização do mento como área doadora e o atendimento em nível ambulatorial com anestesia local, com exceção de um caso. Neste, pela severidade da atrofia, necessitou-se acrescentar fragmentos do corpo e ramo mandibular. Pela extensão do procedimento e pela necessidade de mais de uma área doadora, este foi realizado com anestesia geral. No entanto, os parafusos experimentais foram adaptados somente em fragmentos removidos do mento, para padronização metodológica.

Optou-se pelo mento por ser uma área mais largamente empregada na rotina deste serviço para estas reconstruções. Além disso, conhece-se bem os fenômenos biológicos relacionados ao reparo de áreas onde estes são empregados ${ }^{59}$. 
Em tempo, quando se trata de reparação óssea, uma condição primordial para que ela aconteça de maneira satisfatória é que se consiga a imobilização dos fragmentos envolvidos, independente do tipo de osso que é utilizado. Desde tempos remotos, havia grande preocupação em se imobilizar as regiões de fraturas ósseas a fim de se obter melhores resultados anatômico e funcional ${ }^{25}$. Os métodos de fixação e o tipo de material empregado foram sendo aperfeiçoados até que se chegasse às técnicas de fixação interna, representada por placas e parafusos que permitem a imobilização eficiente de fragmentos ósseos. Trabalhos como o de LA TRENTA et al. ${ }^{49}, 1989$, demonstram bem a superioridade deste tipo de tecnologia quando comparada com os fios de aço que permitem certa mobilidade dos segmentos.

A grande maioria destes materiais é confeccionada em metal, como o aço inoxidável e as ligas de titânio, o que implica na permanência dos mesmos até que se decida por sua remoção. Sobre esta decisão, existe controvérsia entre os autores da área, dividindo-os entre os que defendem a sua permanência ${ }^{17}$ e os que optam pela sua remoção posterior ${ }^{1,34,82,84}$, pela possibilidade de uma eventual reação de 
hipersensibilidade ${ }^{92}$, ou ainda pela colonização bacteriana das superfícies metálicas decorrentes de contaminação local, mesmo na ausência de sinais clínicos ou sintomatologia, conforme estudos realizados por DOBBINS; SELIGSON; RAFF ${ }^{26}$, 1988 e ACERO et al. ${ }^{1}, 1999$.

A detecção de produtos de corrosão dos metais nos tecidos locais e em órgãos distantes é outro fator a ser considerado na manutenção destes materiais $^{45,84,93}$.

Em casos específicos, como os apresentados neste trabalho, a remoção destes materiais torna-se óbvia pela necessidade de instalação dos implantes osteointegráveis, objetivo principal do tratamento. Tal procedimento, apesar de claramente necessário, limita a técnica de reconstrução, e expõe a área enxertada a abordagens mais invasivas, com descolamentos mais extensos. Existem situações clínicas onde seria interessante a sobreposição de blocos de enxertos, o que inviabilizaria a posterior remoção dos parafusos. Além disso, acidentes como 
fraturas da cabeça destes parafusos durante sua remoção, podem comprometer o sítio de instalação dos implantes.

Para evitar estas situações desfavoráveis, aventou-se o emprego de materiais de fixação à base de polímeros sintéticos reabsorvíveis neste tipo de procedimento cirúrgico.

Nos últimos anos, os polímeros sintéticos têm sido empregados para várias finalidades na área de bioengenharia, na forma de materiais de sutura e até mesmo como veículos para medicamentos, ocupando lugar importante na biologia, especialmente os reabsorvíveis como os PGA e PLA, os quais têm apresentado melhor biocompatibilidade ${ }^{67,75}$. Estes polímeros apresentam características próprias que podem ser melhoradas quando se unem na forma de copolímeros, e induzirem respostas biológicas diferentes dependendo do seu proporcionamento ${ }^{22,42}$.

Aproveitando a experiência comprovada da utilização dos polímeros reabsorvíveis na forma de material de fixação, especialmente na área de ortopedia $^{76,97}$, seus componentes foram adaptados para a aplicação em cirurgia 
bucomaxilofacial, nas suas diversas ramificações ${ }^{36}$. Sua grande vantagem recai, justamente, pela não necessidade de remoção posterior, o que expandiu sua aplicação para casos de traumatologia, cirurgia ortognática e reconstrução facial $^{28,29,30,37,47,67,78 .}$

Esta característica, especificamente, incentivou experimentar o comportamento destes materiais nos enxertos ósseos autógenos de pacientes que seriam submetidos à instalação de implantes osteointegráveis, uma vez que a ausência deste tipo de observação na literatura foi evidente.

A preocupação maior com o comportamento biológico de um novo tipo de material em contato com enxertos ósseos nestes casos específicos se justifica pelo fato de que o fenômeno de reparação deve ocorrer da maneira mais satisfatória possível, resultando em um tecido ósseo de qualidade que possa favorecer o fenômeno da osteointegração. Como o processo de degradação destes materiais envolve hidrólise e fagocitose $e^{9,12,13,14,15,31,5,82,88}$, demanda reação inflamatória, cuja extensão poderia comprometer a área enxertada. 
Neste estudo, objetivou-se apenas a verificação do comportamento biológico local de parafusos de PLA e PGA na proporção de 82:18 em enxertos ósseos autógenos corticalizados. Não que sua resistência física seja menos importante, mas pela já comprovada eficiência deste tipo de propriedade em outras situações $^{11,28,29,33,78,90}$. A escolha do sistema LactoSorb (Walter Lorenz Surgical, Jacksonville, E.U.A) se deu principalmente pela sua fácil disponibilidade, e também por ser um dos materiais mais utilizados e pesquisados, como confirmado durante o levantamento bibliográfico $28,29,30,31,32,33,37,47,67,75,78$.

O tempo estabelecido de quatro meses para a obtenção dos espécimes se deve à constatação de que este período já é suficiente para que o enxerto autógeno oriundo da região mentoniana tenha sofrido incorporação ao leito receptor e encontre-se em fase de remodelação, conforme verificado por MATSUMOTO et al. ${ }^{59}$, quando em 2002, compararam o padrão de reparação dos enxertos de ilíaco e mento neste mesmo período. Apesar da reduzida dimensão dos fragmentos ósseos 
obtidos no presente estudo, pôde-se observar a presença de células ósseas e canais de Havers vascularizados, confirmando a viabilidade do tecido.

Para o procedimento de biópsia, utilizou-se broca trefina com diâmetro interno de 2,6mm, suficiente para se obter os parafusos juntamente com porção de tecido ósseo adjacente para realização da análise microscópica. Esta metodologia é aplicada com certa freqüência para verificação de reparação óssea, não trazendo malefícios ao tratamento e/ou paciente ${ }^{10,57,86}$. Como explicitado no material e métodos, os locais de teste localizaram-se em áreas não comprometidas pelo posicionamento do implante.

Os resultados obtidos a partir do presente estudo, destacando a formação de uma faixa de tecido conjuntivo fibroso interposta entre o parafuso reabsorvível e o osso adjacente, corroboram com grande parte dos autores que, em outras situações, também realizaram avaliações microscópicas destes polímeros, essencialmente em trabalhos experimentais com animais e em períodos variáveis de reparação $0^{31,32,90}$ 
Conseqüências desagradáveis resultantes do processo de degradação dos polímeros já foram relatadas por BÖSTMAN et al. ${ }^{14,15}$ na área da ortopedia. Uma resposta comum à presença destes materiais, especialmente aos homopolímeros de PGA e PLA, e em menor escala, aos copolímeros de PLA/PGA, refere-se à formação de edema localizado resultando em formação de fístulas assépticas após dois a quatro meses das cirurgias. Apesar da resolução sem maiores conseqüências, áreas osteolíticas foram visualizadas nestes pacientes próximas ao material de fixação. Microscopicamente, o que se verificou nestes casos foi a presença de um exsudato abundante, infiltrado por células gigantes tipo corpo estranho associadas a fragmentos do polímero, além de leucócitos mono e polimorfonucleares.

Felizmente, reações semelhantes não foram observadas quando da utilização destas fixações neste estudo, em concordância com a grande maioria dos trabalhos em que se emprega este tipo de material na região craniomaxilofacial. Uma ressalva se faz em relação ao caso relatado por KUMAR et al. ${ }^{47}$ (1997), onde 
uma criança de cinco anos, após tratamento de fratura de rebordo infra-orbitária associada a soalho de órbita com fixação reabsorvível, apresentou edema e eritema na região duas semanas após a cirurgia, com resolução após outras duas semanas associada a antibioticoterapia.

Por se tratarem de abordagens cirúrgicas e estruturas ósseas anatomicamente distintas, a dimensão dos materiais utilizados talvez seja o fator principal relacionado às diferentes reações. Nas cirurgias ortopédicas os parafusos utilizados podem alcançar vários centímetros de comprimento, enquanto que em cirurgia facial o tamanho das fixações é consideravelmente menor. Além disto, os casos em que se observou este comportamento foram tratados com materiais de PLA ou PGA na forma de homopolímeros. Sabe-se também que, dependendo do tipo de polímero empregado e, quando na forma de copolímeros, a proporção estabelecida altera a cristalinidade e hidrofobicidade do material, afetando, assim, o padrão de degradação ${ }^{22,89}$. 
Em nossos espécimes, eventuais células gigantes tipo corpo estranho também foram visualizadas associadas ao material, porém, sem a presença significativa de células inflamatórias. Raros osteoclastos foram observados no osso adjacente aos parafusos, revelando baixo índice de reabsorção.

Nestes aspectos, o parafuso de titânio se mostrou muito mais apropriado quando em contato com os enxertos ósseos, confirmando suas características já amplamente conhecidas que o consagraram como favorito quando se trata de tecido ósseo. Dos espécimes analisados, observaram-se, em três, discretas áreas de fibrose na superfície óssea adjacente à superfície dos parafusos, sem evidências de inflamação local. Ao contrário, o tecido ósseo apresentou-se morfologicamente viável e sem sinais de reabsorção ou osteólise. Apesar destes aspectos, em alguns estudos relatou-se a presença de processo inflamatório crônico nos tecidos adjacentes às superfícies metálicas, causado pela liberação de produtos de corrosão, conforme revelado por TORGERSEN et al..$^{93}$, 1995, e JORGENSON et al. ${ }^{45}, 1997$. 
No entanto, no local dos enxertos, nenhum dos pacientes apresentou quaisquer tipos de manifestações clínicas ou radiográficas durante o período pósoperatório que sugerisse uma resposta inflamatória mais exacerbada pela presença dos materiais utilizados.

Os presentes resultados foram obtidos por meio de análise puramente morfológica descritiva. Aventou-se, inicialmente, a necessidade de se realizar análise morfométrica a fim de se obter com precisão numérica a quantidade de tecido ósseo presente adjacente aos parafusos de fixação. Para isto, haveria a necessidade de se manter o parafuso de titânio no osso e realizar seu corte junto com o tecido circunjacente, da mesma maneira como foram preparados os espécimes referentes aos parafusos reabsorvíveis. A escassez de equipamentos próprios no país e a impossibilidade de acesso a eles não permitiram que tal metodologia fosse executada. A necessidade de se remover os parafusos de titânio previamente às biópsias não nos permitiu aplicar métodos morfométricos, pois a fidelidade da interface parafuso/osso, mesmo que em pequenas proporções, foi 
perdida.Apesar dos inconvenientes técnicos, pôde-se notar com clareza a viabilidade óssea em ambos os grupos e definir seus padrões histológicos.

A partir dos resultados obtidos, recomenda-se cautela na utilização dos materiais reabsorvíveis na forma de fixação quando se objetivar a instalação de implantes osteointegráveis. A presença do tecido fibroso interposto não constitui obstáculo à inserção do implante, contudo, a manutenção do material neste período experimental pode interferir durante os procedimentos de fresagem e, posteriormente, não se sabe o efeito de tal manipulação. A espessura desta interface indica, aparentemente, que o polímero proporcionou uma maior reação tecidual inicial que o titânio, repercutindo numa maior perda óssea ao redor dos parafusos reabsorvíveis. No entanto, esta perda, de caráter microscópico, pode não ter representatividade clínica. A cautela deve ser tomada em relação à continuidade deste processo, uma vez que boa parte do parafuso ainda estava presente, com quatro meses de pós-operatório. Além disto, PHILAJAMÄKI et al. ${ }^{76}$ (1992); EPPLEY; SADOVE $^{32}$ (1994); EDWARDS; KIELY; EPPLEY ${ }^{30}$ (2001), valendo-se de análises 
radiográficas e microscópicas, não garantem o preenchimento do espaço previamente ocupado pelo parafuso de fixação por tecido ósseo e constatam a persistência do tecido fibroso após vários meses.

Vale ressaltar que, ambos os materiais permitiram a incorporação dos enxertos e não interferiram na viabilidade e/ou qualidade óssea dos mesmos, sendo que as diferenças permaneceram restritas às regiões de interface tecido/parafuso.

Em face destas observações, nas reconstruções maiores, as fixações reabsorvíveis seriam de grande valia se posicionadas em regiões onde certamente não interferisse na instalação dos implantes, e que não precisariam ser expostas em um segundo momento, evitando assim, grandes descolamentos e conseqüente reabsorção óssea local. Caso contrário, pelos dados aqui obtidos, sugere-se cautela em seu emprego, uma vez que ainda não se sabe ao certo sua repercussão na condução do tratamento. 


\section{CONCLUSÕES}

A partir da análise microscópica morfológica dos espécimes, e respeitando-se as limitações do modelo experimental, nas regiões onde se utilizaram os parafusos de fixação pôde-se observar :

1) tecido ósseo adjacente viável em ambos os grupos, apresentando-se organizado e vascularizado, com ausência de inflamação;

2) que os parafusos de titânio não induziram resposta inflamatória ou reabsorção local do enxerto ósseo;

3) que os parafusos reabsorvíveis proporcionaram resposta inflamatória mais intensa e persistente, caracterizando reação tipo corpo estranho pela presença do material no período avaliado.

Frente a estas evidências, conclui-se que:

- ambos os materiais podem ser utilizados com a finalidade de fixação dos enxertos ósseos. Contudo, deve-se ter cautela no emprego dos parafusos 
reabsorvíveis devido à resposta inflamatória mais prolongada e a persistência do material no período de quatro meses, podendo interferir na seqüência do tratamento quando da utilização de implantes osteointegráveis. 


\section{ANEXO 1 - Parecer favorável do Comitê de Ética em Pesquisa da Universidade do Sagrado Coração}

Universidade do Sagrado Coração

\section{COMITÊ DE ÉTICA EM PESQUISA}

\section{Título do Projeto:}

Avałiação da aplicabilidade de parafusos reabsorviveis na fixação de enxertos ósseos autógenos para reconstruçăo de rebordos e reabilitação com implantes osseointegrados".

Pesquisador responsável: Prof. Dr. Luís Antônio de Assis Taveira

\section{Parecer da Comissão de Ética:}

O projeto foi muito bem elaborado, fundamentado em literatura recente. Além disto contém termo de consentimento pós-informado bern redigido e dentro das normas estabelecidas pela Resolução 196/96 da Comissão Nacional de Ética em Pesquisa, para pesquisas envolvendo seres humanos.

Portanto o projeto está aprovado.

Data da Reunlăo:

19 de setembro de 2001

Assinatura da Coordenadora

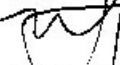

Prof. Dia. Miryam Schuckar 


\section{ANEXO 2 - Distribuição dos eventos microscópicos característicos observados nos espécimes referentes aos parafusos de titânio}

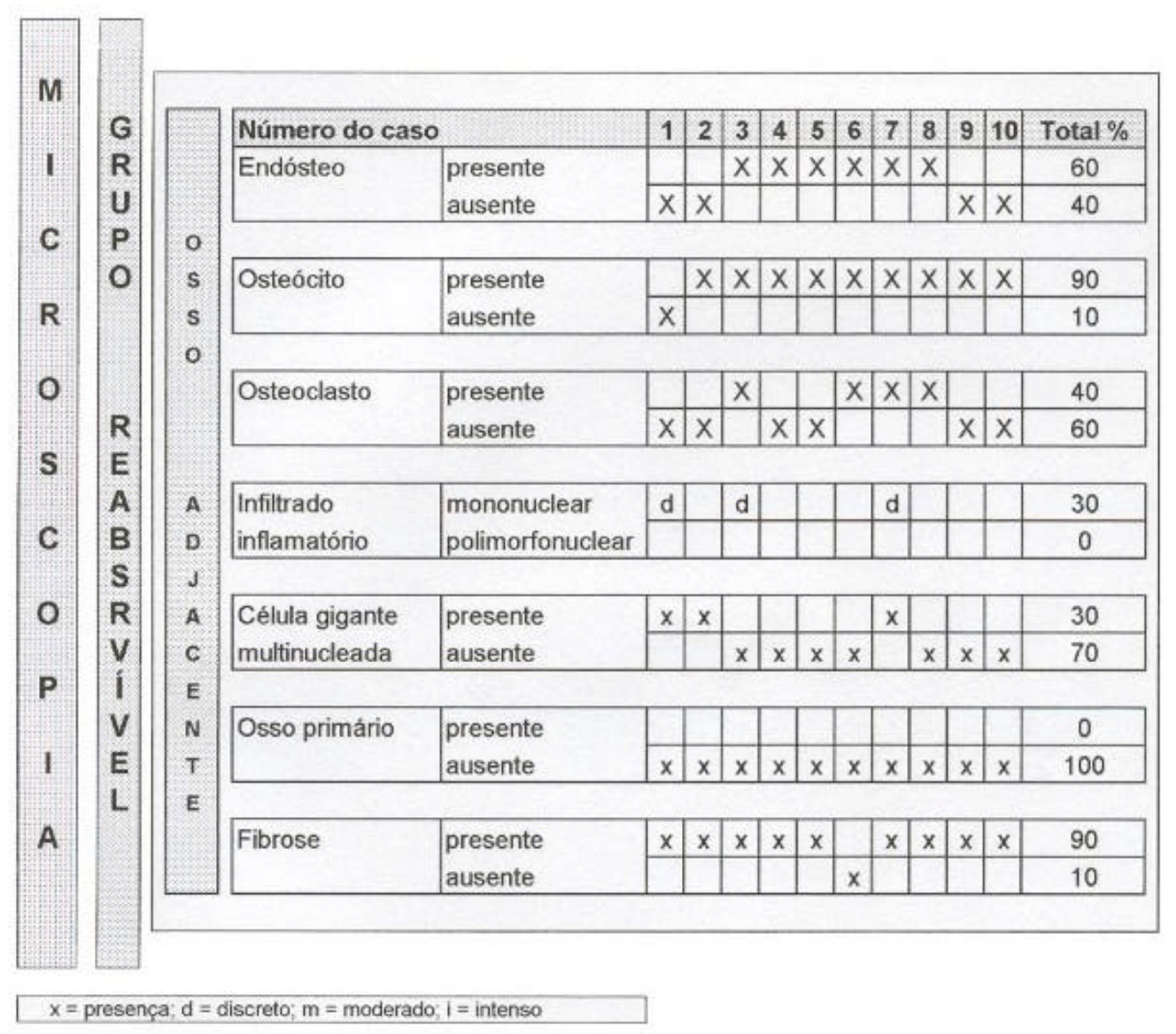


ANEXO 3 - Distribuição dos eventos microscópicos característicos observados nos espécimes referentes aos parafusos reabsorvíveis

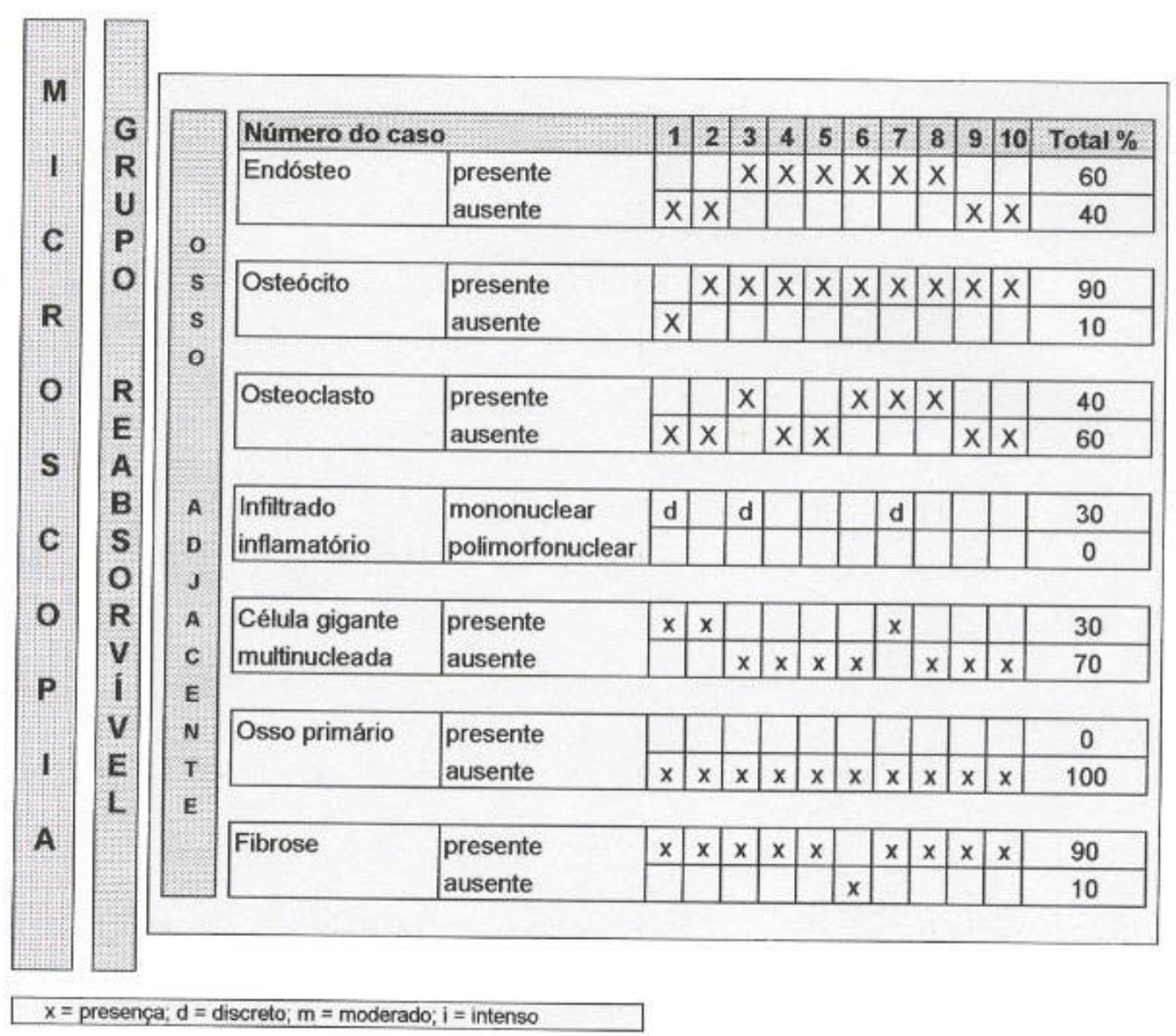




\section{REFERÊNCIAS BIBLIOGRÁFICAS*}

1. ACERO, J. et al. The behaviour of titanium as a biomaterial: microscopy study of plates and surrounding tissues in facial osteosynthesis. J. craniomaxillofac. Surg., v.27, n.2, p.117-23, Apr. 1999.

2. AGRAWAL, C.M.; ATHANASIOU, K.A. Technique to control pH in vicinity of biodegrading PLA-PGA implants. J. Biomed. Mat. Res., v.38, n.2, p.105-14, 1997.

3. AL RUHAIMI, K.A. Bone graft substitutes: a comparative qualitative histologic review of current osteoconductive grafting materials. Int. J. oral Maxillofac. Implants, v.16, n.1, p.105-14, 2001.

4. ALBERIUS, P.; DAHLIN, C.; LINDE, A. Role of osteopromotion in experimental bone grafting to the skull. A study in adult rats using a membrane technique. J. oral Maxillofac. Surg., v.50, n.8, p.829-34, Aug. 1992.

5. ALONSO, N. et al. Cranial versus iliac onlay bone grafts in the facial skeleton: a macroscopic and histomorphometric study. J. craniofac. Surg., v.6, n.2, p.113-8, Mar. 1995.

6. AZEVEDO,R.M. Estabelecimento de um protocolo de avaliação da morbidade da região ilíaca como zona doadora de enxertos ósseos para reconstrução alveolar. Dissertação (Mestrado) - Universidade do Sagrado Coração, Bauru, 110p. 2000.

\footnotetext{
${ }^{*}$ Normas recomendadas para uso no 穃bito da Universidade de S縊 Paulo, com base no documento 迭efer䴲cias Bibliogr畴icas: exemplos emanado do Conselho Supervisor do Sistema Integrado de Bibliotecas da USP , em reuni縊 de 20 de setembro de 1990.
} 
7. BECKER, W. et al. Clinical and histologic observations of sites implanted with intraoral autologous bone grafts or allografts. 15 human case reports. J. Periodont., v.67, n.10, p.1025-33, Oct. 1996.

8. BEDROSSIAN, E.; TAWFILIS, A.; ALIJANIAN, A. Veneer grafting: a technique for augmentation of the resorbed alveolus prior to implant placement. A clinical report. Int. J. oral Maxillofac. Implants, v.15, n.6, p.853-8, Nov./Dec. 2000.

9. BERGSMA, E.J. et al. Foreign body reactions to resorbable poly (L-lactide) bone plates and screws used for the fixation of unstable zygomatic fractures. J. oral Maxillofac. Surg., v.51, n.6, p.666-70, June 1993.

10. BLOMQVIST, J.E. et al. Importance of bone graft quality for implant integration after maxillary sinus reconstruction. Oral Surg. Oral Med. Oral Pathol., v.86, n.3, p.268-74, Sept. 1998.

11. BOS, R.R.M. et al. Bio-absorbable plates and screws for internal fixation of mandibular fractures. A study in six dogs. Int. J. oral Maxillofac. Surg., v.18, n.6, p.365-69, 1988.

12. BÖSTMAN, O.M. Osteolytic changes accompanying degradation of absorbable fracture fixation implants. J. Bone Joint Surg., v.73-B, p.679-82, 1991.

13. BÖSTMAN, O.M.; PIHLAJAMÄKI H.K. Adverse tissue reactions to bioabsorbable fixation devices. Clin. orthop. related Res., n.371, p.216-27, Feb. 2000.

14. BÖSTMAN, O.M. et al. Foreign-body reactions to fracture fixation implants of biodegradable synthetic polymers. J. Bone Joint Surg., v.72-B, p.592-6, 1990. 
15. BÖSTMAN, O. et al. Degradation and tissue replacement of na absorbable polyglycolide screw in the fixation of rabbit femoral osteotomies. J. Bone Joint Surg., v.74-A, n.7, p.1021-31, Aug. 1992.

16. BREINE, U.; BRANEMARK, P-I. Reconstruction of alveolar jaw bone. Scand. J. plast. reconstr. Surg., v.14, n.1, p.14-48, 1980.

17. BROWN, J.S. et al. The fate of miniplates in facial trauma and orthognathic surgery: a retrospective study. Brit. J. oral Maxillofac. Surg., v.27, p.306-15, 1989.

18. CARVALHO, P.S.P.; LUPPINO, F.; BASSI, A.P.F. Biomateriais utilizados em implantodontia. In: GOMES, L.A. Implantes osseointegrados. São Paulo, Editora Santos, 2002. Cap. 4, p.77-92.

19. CAWOOD, J.I.; HOWELL, R.A. A classification of the edentulous jaws. Int. J. oral Maxillofac. Surg., v.17, n.4, p.232-6, 1988.

20. CHAMPY, M. et al. Mandibular osteosynthesis by miniature screws plates via a bucal approach. J. Maxillofac. Surg., v.6, n.1, p.14-21, Feb. 1978.

21. CITARDI, M.J.; FRIEDMAN, C.D. Nonvascularized autogenous bone grafts for craniofacial skeletal augmentation and replacement. Otolaryngol. Clin. $\mathbf{N}$. Amer., v.27, n.5, p.891-910, Oct. 1994.

22. CUTRIGHT, D.E. et al. Degradation rates of polymers and copolymers of polylactic and polyglycolic acids. Oral Surg., v.37, n.1, p.142-52, 1974.

23. DeLACURE, M.D. Physiology of bone healing and bone grafts. Otolaryngol. Clin. N. Amer., v.27, n.5, p.859-74, Oct. 1994. 
24. DEPORTER, D.A. et al. A prospective human clinical trial of endopore dental implants in restoring the partially edentulous maxilla using fixed prostheses. Int. J. oral Maxillofac. Implants, v.16, n.4, p.527-36, July/Aug. 2001.

25. DINGMAN, R.O.; NATVIG, P. Os homens da antiguidade. In: das fraturas faciais. São Paulo, Editora Santos, 1983, Cap. 2, p. 11-42.

26. DOBBINS, J.J.; SELIGSON, D.; RAFF, M.J. Bacterial colonization of orthopedic fixation devices in the abscence of clinical infections. J. Infect. Diseases, v.158, n.1, p.203-5, July 1988.

27. DONOVAN, M.G. et al. Maxillary and mandibular reconstruction using calvarial bone grafts and Branemark implants: a preliminary report. J. oral Maxillofac. Surg., v.52, n.6, p.588-94, June 1994.

28. EDWARDS, R.C.; KIELY, K.D. Resorbable fixation of the Le Fort I osteotomies. J. craniofac. Surg., v.9, n.3, p.210-4, May 1998.

29. EDWARDS, R.C.; KIELY, K.D.; EPPLEY, B.L. Resorbable fixation techniques for genioplasty. J. oral Maxillofac. Surg., v.58, n.3, p.269-72, Mar. 2000.

30. EDWARDS, R.C.; KIELY, K.D.; EPPLEY, B.L. Fixation of bimaxillary osteotomies with resorbable plates and screws: experience in 20 consecutive cases. $\mathbf{J}$. oral Maxillofac. Surg., v.59, n.3, p.271-6, Mar. 2001.

31. EPPLEY, B.L.; REILLY, M.R. Degradation characteristics of PLLA-PGA bone fixation devices. J. craniomaxillofac. Surg., v.8, n.2, p.116-20, Mar. 1997.

32. EPPLEY, B.L.; SADOVE, A.M. A comparison of resorbable and metallic fixation in healing of calvarial bone grafts. Plast. reconstruc. Surg., v.96, n.2, p.31622, 1994. 
33. EPPLEY, B.L.; SARVER, D.; PIETRZAK, B. Biomechanical testing of resorbable screws used for mandibular sagittal split osteotomies. J. oral Maxillofac. Surg., v.57, n.2, p.1431-5, Dec. 1999.

34. FRANCEL, T.J. et al. The fate of plates and screws after facial fracture reconstruction. Plast. reconstr. Surg., v.90, n.4, p.568-73, Oct. 1992.

35. GARG, A.K. et al. Autogenous mandibular bone grafts in the treatment of the resorbed maxillary anterior alveolar ridge: rationale and approach. Implant Dentistry, v.7, n.3, p.169-76, 1998.

36. GETTER, L. et al. A biodegradable intraoseous appliance in the treatment of mandibular fractures. J. oral Surg., v.30, n.5, p.344-8, May 1972.

37. GOLDSTEIN, J.A.; QUERESHY, F.A.; COHEN, A.R. Early experience with biodegradable fixation for congenital pediatric craniofacial surgery. J. craniomaxillofac. Surg., v.8, n.2, p. 110-5, Mar. 1997.

38. HARDESTY, R.A.; MARSH, J.L. Craniofacial onlay bone grafting: a prospective evaluation of graft morphology, orientation, and embryonic origin. Plast. reconstr. Surg., v.85, n.1, p.5-14, Jan. 1990.

39. HESLOP, I.H. et al. Mandibular fractures: treatment by closed reduction and direct skeletal fixation. In: WILLIAMS, J.L. Rowe and William's maxillofacial injuries. $2^{\mathrm{a}}$ ed. New York, Churchill Livingstone, 1994. Cap. 12, p.341-86.

40. HOPPENREIJS, T.J.M.; NIDJAM, E.S.; FREIHOFER, H.P.M. The chin as a donor site in early secondary osteoplasty: a retrospective clinical and radiological evaluation. J. craniomaxillofac. Surg., v.20, n.3, p.119-24, Apr. 1992. 
41. ISAKSSON, S.; ALBERIUS, P. Maxillary alveolar ridge augmentation with onlay bone-grafts and immediate endosseous implants. J. craniomaxillofac. Surg., v.20, n.1, p.2-7, Jan. 1992.

42. JAMES, K. et al. Small changes in chemical structure of a polymer can have a significant effect on the hard-tissue response in vivo. In: DAVIES, J.E. Bone engineering. Toronto, $\mathrm{Em}^{2}$, 2000.Cap. 17, p.195-203.

43. JOHANSSON, B. et al. A clinical study of changes in the volume of bone grafts in the atrophic maxilla. Dentomaxillofac. Radiol., v. 30, n.3, p.157-61, May 2001.

44. JOOS, U.; KLEINHEINZ J. Reconstruction of the severely resorbed (Class VI) jaws: routine or exception? J. craniomaxillofac. Surg., v.28, n.1, p.1-4, Feb. 2000.

45. JORGENSON, D.S. et al. Detection of titanium in human tissues after craniofacial surgery. Plast. reconstr. Surg., v.99, n.4, p. 976-81, Apr. 1997.

46. KELLER, E.; TOLMAN, D.E.; ECKERT, S. Surgical-prosthodontic reconstruction of advanced maxillary bone compromise with autogenous onlay block bone grafts and osseointegrated endosseous implants: a 12-year study of 32 consecutive patients. Int. J. oral Maxillofac. Implants, v.14, n.2, p.197-209, Mar./Apr. 1999.

47. KUMAR, A.V. et al. Bioabsorbable plates and screws in pediatric craniofacial surgery: a review of 22 cases. J. craniomaxillofac. Surg., v.8, n.2, p.97-9, Mar. 1997.

48. KUSIAK, J.F.; ZINS, J.E.; WHITAKER, L.A. the early revascularization of membranous bone. Plast. reconstr. Surg., v.76, n.4, p.510-6, Oct. 1985. 
49. LA TRENTA, G.S. et al. The role of rigid skeletal fixation in bone-graft augmentation of the craniofacial skeleton. Plast. reconstr. Surg., v.84, n.4, p.578-88, Oct. 1989.

50. LAURIE, S.W.S. et al. Donor-site morbidity after harvesting rib and iliac bone. Plast. reconstr. Surg., v.73, n.6, p.933-8, June 1984.

51. LEE, M.B. Bone morphogenetic proteins: background and implications for oral reconstruction. A review. J. clin. Periodont., v.24, n.6, p.355-65, June 1997.

52. LEKHOLM, U. et al. Oral implants in combination with bone grafts. A 3-year retrospective multicenter study using the Branemark implant system. Int. J. oral Maxillofac. Surg., v.28, n.3, p.181-7, June 1999.

53. LEVIN, L.M. et al. Bone induction and the biology of grafting. In: FONSECA, R.J.; DAVIS, W.H. Reconstructive preprosthetic oral and maxillofacial surgery. $2^{\mathrm{a}}$ ed. Phidadelphia, W.B. Saunders, 1995. Cap.3, p.41-72.

54. LI, K.K.; STEPHENS, W.L.; GLIKLICH, R. Reconstruction of the severely atrophic edentulous maxilla using Le Fort I osteotomy with simultaneous bone graft and implant placement. J. oral Maxillofac. Surg., v.54, n.5, p.542-6, May 1996.

55. LI, S. Hydrolitic degradation characteristics of aliphatic polyesters derived from lactic and glycolic acids. J. Biomed. mater. Res., v.48, n.3, p.342-53, 1999.

56. LIN, K.Y. et al. The effect of rigid fixation on the survival of onlay bone grafts: an experimental study. Plast. reconstr. Surg., v.86, n.3, p.449-56, Sept. 1990. 
57. LUNDGREN, S. et al. Simultaneous or delayed placement of titanium implants in free autogenous iliac bone grafts. Int. J. oral Maxillofac. Surg., v.28, n.1, p.31-7, Feb. 1999.

58. MARX, R.E. Clinical application of bone biology to mandibular and maxillary reconstruction. Clin. plast. Surg., v.21, n.3, p.377-92, July 1994.

59. MATSUMOTO, M.A. et al. Microscopic analysis of reconstructed maxillary aveolar ridges using autogenous bone grafts from the chin and iliac crest. Int. J. oral Maxillofac. Implants, v.17, n.4, p.507-16, July/Aug. 2002.

60. MERAW, S.J. et al. Retrospective review of grafting techniques utilized in conjunction with endosseous implant placement. Int. J. oral Maxillofac. Implants, v.14, n.5, p.744-7, Sept./Oct. 1999.

61. MICHELET, F.X.; DEYMES, J.; DESSUS, B. Osteosynthesis with miniaturized screwed plates in maxillo-facial surgery. J. oral Maxillofac. Surg., v.1, p.7984, June 1973.

62. MISCH, C.E. Edentulous alveolar ridge augmentation and restorative grafting. In:_ Contemporary implant dentistry. St. Louis, Mosby, 1993. Cap. 20, p.419-43.

63. MISCH, C.M. Ridge augmentation using mandibular ramus bone grafts for the placement of dental implants: presentation of a technique. Pract. period. Aesthetic Dent., v.8, n.2, p.127-35, Mar. 1996.

64. MISCH, C.M. Comparison of intraoral donor sites for onlay grafting prior to implant placement. Int. J. oral Maxillofac. Implants, v.12, n.6, p.767-76, Nov./Dec. 1997. 
65. MISCH, C.M.; MISCH, C.E. The repair of localized severe ridge defects for implant placement using mandibular bone grafts. Implant Dentistry, v.4, n.4, p.261-7, 1995.

66. MISCH, C.M. et al. Reconstruction of maxillary alveolar defects with mandibular symphisis grafts for dental implants: a preliminary procedural report. Int. J. oral Maxillofac. Implants, v.7, n. 3, p.360-6, 1992.

67. MONTAG, M.E.; MORALES JR., L.; DAANE, S. Bioabsorbables: their use in pediatric craniofacial surgery. J. craniomaxillofac. Surg., v.8, n.2, p. 100-2, Mar. 1997.

68. NARY FILHO, H.; FRANCISCHONE, C.E.; SARTORI, I.A.M. Considerações sobre o uso da fixação zigomática no tratamento de maxilas atróficas. In: GOMES, L.A. Implantes osseointegrados. São Paulo, Editora Santos, 2002. Cap. 9, p.143-56.

69. NARY FILHO, H.; ILG, J.P. Atrofia severa de maxilla. In: DINATO, J.C.; POLIDO, W.D. Implantes osseointegrados. cirurgia e prótese. São Paulo, Editora Artes Médicas, 2001. Cap. 17, p.343-72.

70. OKAMOTO, T. et al. Implante de osso anorgânico em cavidade óssea: estudo histológico em ratos. Rev. Odont. UNESP, v.23, n.2, p.213-9, jul./dez. 1994.

71. OZAKI, W.; BUCHMAN, S.R. Volume maintenance of onlay bone grafts in the craniofacial skeleton: micro-architeture versus embryologic origin. Plast. reconstr. Surg., v.102, n.2, p.291-9, 1998.

72. OZAKI, W. et al. A comparative analysis of the microarchitecture of cortical membranous and cortical endochondral onlay bone grafts in the craniofacial skeleton. Plast. reconstr. Surg., v.104, n.1, p.139-47, 1999. 
73. PHILLIPS, J.H.; RAHN, B.A. Fixation effects on membranous and endochondral onlay bone graft revascularization and bone deposition. Plast. reconstr. Surg., v.85, n.6, p.891-7, June 1990.

74. PIETRZAK, W.S.; SARVER, D.R.; VERSTYNEN, M.L. Bioresorbable implants practical considerations. Bone, v.19, n.1, p.109S-19S, July 1996.

75. PIETRZAK, W.S.; SARVER, D.R.; VERSTYNEN, M.L. Bioabsorbable polymer science for the practicing surgeon. J. craniomaxillofac. Surg., v.8, n.2, p.8791, Mar. 1997.

76. PIHLAJAMÄKI, $\mathrm{H}$. et al. Absorbable pins of self-reinforced poly-L-lactic acid for fixation of fractures and osteotomies. J. Bone Joint Surg., v.74, n.6, p.853-7, 1992

77. PINHOLT, E.M. et al. Revascularization of calvarial, mandibular, tibial, and iliac bone grafts in rats. Ann. plastic. Surg., v.33, n.2, p.193-7, Aug. 1994.

78. QUERESHY, F. A. et al. The efficacy of bioresorbable fixation in the repair of mandibular fractures: an animal study. J. oral Maxillofac. Surg., v.58, n.11, p.1263-9, Nov. 2000.

79. RABIE, A.B.M.; LIE KEN JIE, R.K.P. Integration of endochondral bone grafts in the presence of demineralized bone matrix. Int. J. oral Maxillofac. Surg., v.25, n.4, p.311-8, Aug. 1996.

80. RAGHOEBAR, G.M. et al. Augmentation of localized defects of the anterior maxillary ridge with autogenous bone before insertion of implants. J. oral Maxillofac. Surg., v.54, n.10, p.1180-6, Oct. 1996. 
81. RASMUSSON, L. et al. Stability assessments and histology of titanium implants placed simultaneously with autogenous onlay bone in the rabbit tibia. Int. J. oral Maxillofac. Surg., v.27, n.3, p.229-35, June 1998.

82. SANTAVIRTA, S. et al. Immune response to polyglycolic acid implants. J. Bone Joint Surg., v.72-B, n.4, p.597-600, 1990.

83. SCHLIEPHAKE, H.; NEUKAM, F.W.; WICHMANN, M. Survival analysis of endosseous implants in bone grafts used for the treatment of severe alveolar ridge atrophy. J. oral Maxillofac. Surg., v.55,n.11, p.1227-33, Nov. 1997.

84. SCHLIEPHAKE, $H$. et al. Metal release from titanium fixtures during placement in the mandible: an experimental study. Int. J. oral Maxillofac. Implants, v.8, n.5, p.502-11, 1993.

85. SETHI, A.; KAUS, T. Ridge augmentation using mandibular block bone grafts: preliminary results of an ongoing prospective study. Int. J. oral Maxillofac. Implants, v.16, n.3, p.378-88, May/June 2001.

86. SHIROTA, T. et al. Histologic and microradiologic comparison of block and particulate cancellous bone and marrow grafts in reconstructed mandibles being considered for dental implant placement. J. oral Maxillofac. Surg., v.54, n.1, p.15-20, Jan. 1996.

87. SOLHEIM, E. et al. Bone formation in cranial, mandibular, tibial, and iliac bone grafts in rats. J. craniofac. Surg., v.6,n.2, p.139-42, Mar. 1995.

88. TABATA, Y.; IKADA, Y. Macrophage phagocytosis of biodegradable microspheres composed of L-lactic acid/glycolic acid homo- and copolymers. J. Biomed. mater. Res., v.22, n.10, p.837-58, 1988. 
89. TEMENOFF, J.S.; LU, L.; MIKOS, A.G. Bone-tissue engineering using synthetic biodegradable polymer scaffolds. In: DAVIES, J.E. Bone engineering. Toronto, em² incorporated, 2000, Cap. 42, p.454-61.

90. THALLER, S.R. et al. Cranial bone grafting: biodegradable versus titanium fixation in a rabbit model. J. craniofac. Surg., v.7, n.1, p.54-9, Jan. 1996.

91. TOLMAN, D.E. Reconstructive procedures with endosseous implants in grafted bone: a review of the literature. Int. J. oral Maxillofac. Surg., v.10, n.3, p.27594, May/June 1995.

92. TORGERSEN, S.; GILHUUS-MOE, O.T.; GJERDET, N.R. Immune response to nickel and some clinical observations after stainless steel miniplate osteosynthesis. Int. J. oral Maxillofac. Surg., v.22, n.4, p.246-50, Aug. 1993.

93. TORGERSEN, S. et al. Metal particles and tissue changes adjacent to miniplates. A retrieval study. Acta odontol. Scand., v.53, n.2, p.67-71, Apr. 1995.

94. TRIPLETT, R.G.; SCHOW, S.R. Autologous bone grafts and endosseous implants: complementary techniques. J. oral Maxillofac. Surg., v.54, n.4, p.486-34, Apr. 1996.

95. TULER, R.F.; NARY FILHO, H. Avaliação da morbidade da região mentoniana como área doadora para enxertos ósseos autógenos. In: Reunião Anual da Sociedade Brasileira de Pesquisa Odontológica, 16, Águas de São Pedro, 1999. Anais. São Paulo, SBPqO, 1999. P.48/Resumo A172/

96. WIDMARK, G.; CARLSSON, G.E.; IVANOFF, C.J. Rehabilitation of patients with severely resorbed maxillae by means of implants with or without bone grafts: a 3- to 5-year follow-up clinical report. Int. J oral Maxillofac. Implants, v.16, n.1, p.73-9, 2001. 
97. YAMAMURO, T. et al. Bioabsorbable osteosynthetic implants of ultra high strength poly-L-lactide. Int. orthop., v.18, n.6, p.332-40, 1994.

98. YASZEMSKI, M.J. et al. Evolution of bone transplantation: molecular, cellular and tissue strategies to engineer human bone. Biomaterials, v.17, n.2, p.175-85, 1996.

99. ZINS, J.E.; WHITAKER, L.A. Membranous versus endochondral bone: implications for craniofacial reconstruction. Plast. reconstr. Surg., v.72. n.6, p.778-85, Dec. 1983. 


\section{EVALUATION OF TISSUE RESPONSE DUE TO DIFFERENT FIXATION}

\section{MATERIALS IN AUTOGENOUS BONE GRAFTS. MICROSCOPIC}

\section{MORPHOLOGICAL ANALYSIS.}

Autogenous bone grafts have been largely used for the reconstruction of severely atrophic ridges. The fixation of these grafts plays an important role in bone graft repair, leading to the integration to the receptor bed and early revascularization. Resorbable plates and screws are being developed in an attempt to minimize some negative aspects of the metallic devices routinely used in this procedure. The present work evaluated comparatively local bone conditions of autogenous grafts retrieved from the chin, in contact with polyglicolic / poly (L-lactic) acid and titanium screws. Seven patients presenting severe maxillary atrophy, unabling rehabilitation with endosseous implants, participated in this study. After four months of the grafting, the regions containing the test screws were biopsied using trephine bur, the specimens retrieved undergone histological routine procedures, and stained with HE and Mallory Trichromic to be morphologically evaluated under light microscopy. From this analysis, viable bone tissue was noted around the titanium screws, eventually presenting lining cells with no signs of resorption. Around the resorbable screws, viable bone tissue was also observed, although, presenting a thick layer of connective tissue interposed between the screw and the bone, and eventual foreign body giant cells. These results suggest that both fixation method provided good 
condition of local repair, however, the resorbable screws induced a longer inflammatory phase than the titanium screws, characterized by foreign body reaction. 